\title{
Genetic relations between the Aves Ridge and the Grenada back-arc Basin, East Caribbean Sea
}

Clément Garrocq ${ }^{1}$, Serge Lallemand ${ }^{1}$, Boris Marcaillou $^{2}$, Jean-Frédéric Lebrun ${ }^{3}$, Crelia Padron $^{4,5}$, Frauke Klingelhoefer ${ }^{5}$, Mireille Laigle ${ }^{2}$, Philippe Münch ${ }^{1}$, Aurélien Gay ${ }^{1}$, Laure Schenini $^{2}$, Marie-Odile Beslier ${ }^{2}$, Jean-Jacques Cornée ${ }^{1}$, Bernard Mercier de Lépinay ${ }^{2}$, Frédéric Quillévéré 6 , Marcelle BouDagher-Fadel ${ }^{7}$ and the GARANTI cruise team

\footnotetext{
${ }^{1}$ Géosciences Montpellier, CNRS, Université de Montpellier, Université des Antilles, Place Eugène Bataillon, 34095 Montpellier, France

${ }^{2}$ Géoazur, Université Côte d'Azur, CNRS, IRD, Observatoire de la Côte d'Azur, Géoazur, 250 Avenue Albert Einstein, 06560 Valbonne, France

${ }^{3}$ Géosciences Montpellier, Université des Antilles, CNRS, Université de Montpellier, Campus de Fouillole, Pointe-à-Pitre, Guadeloupe, France

${ }^{4}$ Departamento de Ciencias de la Tierra, Universidad Simón Bolívar (USB), Caracas, Venezuela.

${ }^{5}$ Géosciences Marines, Ifremer, ZI de la Pointe du Diable, CS 10070, 29280 Plouzané, France

${ }^{6}$ Université de Lyon, Université Claude Bernard Lyon 1, LGLTPE, CNRS, Bd du 11 Novembre 1918, 69622 Villeurbanne, France

${ }^{7}$ Office of the Vice-Provost (research), University College London, 2 Taviton street, London WC1h 0BT, UK
}

\section{Key Points:}

- Paleocene to early Eocene rifting and middle Eocene spreading generated the asymmetrical Grenada Basin, initially wider in the south

- The southern Lesser Antilles Arc rose in the late Oligocene-Miocene as a result of tectonic shortening in the southeastern Grenada Basin

- The initially subaerial Aves Ridge has subsided since at least the middle Eocene, with a slowdown or even an uplift in the late Oligocene

This article has been accepted for publication and undergone full peer review but has not been through the copyediting, typesetting, pagination and proofreading process, which may lead to differences between this version and the Version of Record. Please cite this article as doi: 10.1029/2020JB020466. 


\begin{abstract}
The Grenada Basin separates the active Lesser Antilles Arc from the Aves Ridge, described as a Cretaceous-Paleocene remnant of the 'Great Arc of the Caribbean'. Although various tectonic models have been proposed for the opening of the Grenada Basin, the data on which they rely are insufficient to reach definitive conclusions. This paper presents a large set of deep-penetrating multichannel seismic reflection data and dredge samples acquired during the GARANTI cruise in 2017. By combining them with published data including seismic reflection data, wide-angle seismic data, well data and dredges, we refine the understanding of the basement structure, depositional history, tectonic deformation and vertical motions of the Grenada Basin and its margins as follows: 1) rifting occurred during the late Paleocene-early Eocene in a NW-SE direction and led to seafloor spreading during the middle Eocene; 2) this newly formed oceanic crust now extends across the eastern Grenada Basin between the latitude of Grenada and Martinique; 3) asymmetrical pre-Miocene depocenters support the hypothesis that the southern Grenada Basin originally extended beneath the present-day southern Lesser Antilles Arc and probably partly into the present-day forearc before the late Oligocene-Miocene rise of the Lesser Antilles Arc; 4) the Aves Ridge has subsided along with the Grenada Basin since at least the middle Eocene, with a general subsidence slowdown or even an uplift during the late Oligocene, and a sharp acceleration on its southeastern flank during the late Miocene. Until this acceleration of subsidence, several bathymetric highs remained shallow enough to develop carbonate platforms.
\end{abstract}

\title{
1. Introduction
}

The Grenada Basin is bounded to the east by the active Lesser Antilles Arc, to the west by the north-south trending Aves Ridge, commonly described as a Cretaceous-Paleocene remnant of the 'Great Arc of the Caribbean' (Burke, 1988), and to the south by the transpressional plate boundary with South America (Figure 1). This setting led previous authors to propose various models for the origin of the Grenada Basin, most of them assuming the basin to be at least partly floored by oceanic crust that was formed during the Paleogene (e.g. Bouysse, 1984; Kearey, 1974; Pinet et al., 1985). These models involve very different mechanisms, such as trapping of Atlantic crust (Donnelly, 1975; Malfait \& Dinkelman, 1972), back-arc extension (Allen et al., 2019; Bird et al., 1999; Bouysse, 1988; Tomblin, 1975), forearc extension (Aitken et al., 2011) or intra-arc detachment faulting (Arnaiz-Rodríguez \& Audemard, 2018; Pindell \& Kennan, 2009). As previous seismic surveys focused on specific parts of the Grenada Basin and did not explore the complete back-arc region, the data available so far have not yet led to any definitive conclusions.

Besides the origin of the Grenada Basin, several related issues therefore remain not completely resolved, including 1) its age of formation and the direction of extension (and possibly seafloor spreading) when the basin opened; 2) the lateral extent of the suspected oceanic crust and its relations with the basin margins; 3 ) the overall sediment distribution over the back-arc area; 4) the vertical motions and their paleogeographic implications, especially for the Aves Ridge (Iturralde-Vinent \& MacPhee, 1999).

To answer such questions, this study aims to provide a comprehensive view of the basement structure and sedimentary architecture of the Grenada Basin and its margins. In this paper we present seismic reflection data acquired in the Lesser Antilles back-arc during the GARANTI cruise (Lebrun \& Lallemand, 2017) (Figure 2). We integrate these data with wide-angle seismic data acquired along three profiles in the study region (Padron et al., in press).

This article is protected by copyright. All rights reserved. 


\section{Regional setting}

\subsection{Plate tectonic setting}

The Grenada Basin is located along the eastern Caribbean plate margin, under which the Atlantic lithosphere of the North and South American plates is subducting. North and south, this arcuate subduction zone turns into east-west strike-slip plate boundaries accommodating the eastward motion of the Caribbean plate relative to the American plates (Figure 1), which is currently about $20 \mathrm{~mm} / \mathrm{yr}$ according to GPS studies (DeMets et al., 2000; Jouanne et al., 2011; Pérez et al., 2001, 2018; Reinoza et al., 2015; Weber et al., 2001). In the south, the El Pilar right-lateral and transpressional strike-slip fault zone (Figure 1) may be the surface expression of a Subduction-Transform Edge Propagator (STEP) formed due to lithospheric tearing in the South American plate (S. A. Clark et al., 2008; Govers \& Wortel, 2005).

Most studies assume that the oceanic interior of the Caribbean Plate developed as an oceanic plateau (Caribbean Plateau) upon the Pacific plate during the Late Cretaceous as it migrated to its current position between the North and South American plates (Pindell, 1994). In plate kinematic reconstructions (Boschman et al., 2014; Pindell \& Kennan, 2009), this eastward migration relative to the American plates has been accompanied by continuous west-dipping subduction of Atlantic (proto-Caribbean) lithosphere beneath the eastern Caribbean plate margin, thereby forming the 'Great Arc of the Caribbean' (Burke, 1988). Cretaceous to

Paleocene remnants of this arc are found in the Greater Antilles (Iturralde-Vinent et al., 2016; Jolly et al., 2008), Aves Ridge (Bouysse et al., 1985; Fox et al., 1971; Nagle, 1972; Neill et al., 2011), and Leeward Antilles (Neill et al., 2011; Santamaría \& Schubert, 1974; J. E. Wright \& Wyld, 2011). During the Cenozoic, the Caribbean and South American plates converged obliquely (Pindell \& Barrett, 1990). This resulted in transpressional deformation that propagated in a diachronous way over $1500 \mathrm{~km}$ from western Venezuela to the current point of convergence offshore Trinidad (Babb \& Mann, 1999; Escalona \& Mann, 2011; Pindell et al., 1991). South of the Grenada Basin, the consequent deformation front extends from the southern end of the Aves Ridge (Los Hermanos spur) to the island of Carriacou in the Grenadines (Figure 1) (Aitken et al., 2011; Pindell \& Kennan, 2007; Pinet et al., 1985; Ysaccis, 1997). This front has not been active since $10 \mathrm{Ma}$ (Pindell \& Kennan, 2007), as post-middle Miocene sediments seal transpressional deformation (Aitken et al., 2011).

\subsection{The Grenada Basin and neighboring arcs}

The up to $150 \mathrm{~km}$-wide crescent-shaped Grenada Basin is bounded to the west by the Aves Ridge, to the east by the Lesser Antilles Arc (Figure 1), and to the south by the shallow Venezuelan continental shelf $(\sim 100 \mathrm{~m}$ deep), on which lies the inverted Carúpano Basin (Ysaccis, 1997) (Figure 2). Between $12^{\circ} \mathrm{N}$ and $15^{\circ} \mathrm{N}$, the basin has a flat seafloor and water depths ranging from 2900 to $3000 \mathrm{~m}$. North of $15^{\circ} \mathrm{N}$, the bathymetry becomes shallower and rougher. In the southern Grenada Basin, wide-angle seismic surveys have revealed a sediment thickness of up to $13 \mathrm{~km}$ deposited upon an igneous crust with oceanic-type geophysical properties (Allen et al., 2019; Boynton et al., 1979; Christeson et al., 2008). The thick sedimentary fill and the low heat-flow values in the Grenada Basin (T. F. Clark et al., 1978; Manga et al., 2012) suggest that the crust is older than 40 Ma (Bouysse, 1988; Holcombe et al., 1990).

The Aves Ridge is a NS-trending submarine edifice that extends over $600 \mathrm{~km}$ from La Blanquilla Island in the south to the Saba Bank in the north (Figure 1). The ridge rises about $2000 \mathrm{~m}$ above the adjacent Venezuela and Grenada basins, with local highs reaching up to a

This article is protected by copyright. All rights reserved. 
few hundred meters below the sea surface. One of them partly emerges and forms the Aves Island (Figure 2). Prominent straight north-south trending ridge crests characterize the western flank, whereas the eastern flank has a convex shape and lower reliefs. From 13 to $17^{\circ} \mathrm{N}$, the Aves Ridge has an average width of $140 \mathrm{~km}$. South of $13^{\circ} \mathrm{N}$, the ridge progressively narrows down to $30 \mathrm{~km}$. The slope of the eastern flank dips about $5^{\circ}$ in the north and becomes steeper to the south $\left(>25^{\circ}\right)$, trending $\mathrm{N} 30^{\circ}$, as the ridge narrows (Figure 1). The Aves Ridge is described as a segment of the Great Arc of the Caribbean that formed at $~ 80-75 \mathrm{Ma}$ (Neill et al., 2011), based on calc-alkaline rocks dredged on Los Hermanos Spur (Fox et al., 1971; Nagle, 1972) (dredge locations in Figure 2). Granodiorites exposed on La Blanquilla Island (Figure 1) represent the youngest arc rocks related to the Aves Ridge with an age of $\sim 59 \mathrm{Ma}$ (J. E. Wright \& Wyld, 2011).

The Lesser Antilles Arc results from the subduction of the Atlantic oceanic lithosphere of the American plates beneath the Caribbean plate. It extends over $850 \mathrm{~km}$ from the Venezuelan continental margin to the Anegada Passage (Figure 1). North of Martinique, the arc splits into two segments: the extinct 'outer arc', also known as the 'Limestone Caribbees', in the east and the active 'inner arc' in the west (Figure 1). Both segments are built on an extinct Cretaceous arc, which is exposed on La Désirade Island, east of Guadeloupe (Bouysse \& Guennoc, 1983; Corsini et al., 2011; Neill et al., 2010). The outer arc was active from the middle Eocene to the early Miocene(Andreieff et al., 1988; Briden et al., 1979; Legendre et al., 2018; Nagle et al., 1976), while the inner arc has been active since the Late MiocenePliocene (Germa et al., 2011; Labanieh et al., 2010). South of Martinique, the inner and outer arcs merge into a single Late Eocene to Recent island arc that separates the Grenada Basin to the west from the Tobago Basin to the east. Alternatively, the southern part of the Eocene outer arc might be buried east of the Tobago Basin, on the basis of magnetic anomalies (Allen et al., 2019).

\subsection{Previous models for the Grenada Basin}

Early models considered the Grenada Basin as a portion of Atlantic oceanic crust that would have been trapped by an eastward jump in the arc magmatism (Donnelly, 1975; Malfait \& Dinkelman, 1972). In that case, the paleo-subduction front should be located between the Aves Ridge and the Grenada Basin. Further studies pointed out the lack of typical forearc features in the Grenada Basin and instead proposed that the basin was formed by back-arc opening, i.e. by rifting of the proto-Lesser Antilles away from the Aves Ridge (Tomblin, 1975).

Back-arc opening is classically described as the result of intra-arc extension due to slab rollback with respect to the upper plate, leading to the formation of a basin that divides the arc into an active segment close to the trench and a remnant one moving away from the trench as the basin opens (Dewey, 1980; Karig, 1972). Continued extension can lead to back-arc spreading, which can occur in various modes depending on the driving forces (Honza, 1995; Taylor, 2013). Although most of the back-arc models proposed for the Grenada Basin share common features, the authors disagree on the style and direction of opening. Various interpretations of magnetic anomalies provide possible spreading orientations ranging from east-west (Bird et al., 1999), northeast-southwest (Bouysse, 1988) to north-south (Pindell \& Barrett, 1990).

One major issue related to these back-arc models is the location of the active arc during oceanic spreading. Alternative models thus suggest the formation of a large forearc (Aitken et al., 2011; Pindell \& Kennan, 2009) or back-arc (Allen et al., 2019) oceanic basin

This article is protected by copyright. All rights reserved. 
encompassing the present-day Grenada and Tobago basins, later intruded by the Lesser Antilles Arc. Pindell \& Kennan (2009) suggest a low-angle detachment mechanism of opening that evolved into seafloor spreading. In this model, the Margarita and Tobago metamorphic terranes are the exhumed footwall of the detachment fault, with the Aves Ridge as the hanging wall. Based on gravity data, Arnaiz-Rodríguez \& Audemard (2018) suggest the same mechanism of opening, but with the Lesser Antilles as the footwall instead of Margarita and Tobago. This makes this model more related to the previously mentioned back-arc models, although the authors do not consider any seafloor spreading. The model of Aitken et al. (2011), mostly based on seismic data, suggests a different mechanism of forearc opening controlled by flexural subsidence. Recently, Allen et al. (2019) have suggested a back-arc opening behind an arc that would be partly buried east of the Tobago, on the basis of magnetic anomalies. These alternative models need further constraints as 1) oceanic forearc spreading is extremely rare and generally very localized within a rift perpendicular to the trench as in the southern Mariana forearc (Ribeiro et al., 2013, 2015), and 2) no island-arc volcanic rocks contemporaneous with the Grenada Basin opening have been found yet.

\section{Data acquisition and processing}

In this paper, we present deep-penetration multichannel seismic reflection (MCS) data acquired during the GARANTI cruise onboard $R / V$ L'Atalante (Lebrun \& Lallemand, 2017) (Figure 2). Wide-angle seismic (WAS) data were also recorded along three lines, two of which are shown in Figure 2: one trending E-W across the basin and its margins (GA02) and the other along-strike in the axis of the basin (GA01). The processing and interpretation of the GARANTI WAS data are the subject of a companion paper (Padron et al., in press).

MCS data were collected using a 6473 in $^{3}$ airgun array of 16 seismic sources with a $9-40 \mathrm{~Hz}$ frequency range, and a $4.5 \mathrm{~km}$-long, 720 -channel streamer. The data were quality-controlled and binned in common midpoint (CMP) gathers every 12.5 meters using SolidQC (Ifremer) before being processed using the Geovation software (CGG).

The processing sequence of MCS data on Geovation included trace resampling from 2 to 4 ms, application of a bandpass filter $(3,5,120,125 \mathrm{~Hz})$, noise attenuation, spherical divergence correction, velocity analysis on CMP gathers, multiple removal by using surfacerelated multiple elimination and parabolic radon-transform techniques, predictive deconvolution, normal moveout (NMO) and dip moveout (DMO) corrections before 60-fold stack, and post-stack time migration at constant seawater velocity $(1500 \mathrm{~m} / \mathrm{s})$.

In addition to the GARANTI dataset, we used published seismic data including line BOL30 acquired during the BOLIVAR cruise (Sawyer \& Mann, 2004) and Gulfrex seismic lines (Aitken et al., 2011) (Figure 2). This allows us to extend our seismic grid to the south to make the link between the Grenada and Carúpano Basins (Figure 2).

Seismic horizons were gridded after picking to produce isochron maps. Using velocity models derived from the GARANTI WAS data (Padron et al., in press), we took the average interval velocity of each seismic unit to produce isopach maps. We calibrated the seismic units using offshore well data and onshore geological observations (Figure 3). We also used dredge results from previous studies (Bouysse et al., 1985; Fox et al., 1971; Marlowe, 1971) and six new dredge hauls carried out during the GARANTI cruise on bathymetric highs on the eastern flank of the Aves Ridge (Figure 2). Thin sections were made from twelve collected carbonate rock samples to identify their microfacies and fossil content (Table A1). The identified microfacies were attributed to a depositional environment following the classification of $(\mathrm{V}$.

This article is protected by copyright. All rights reserved. 
P. Wright \& Burchette, 1996), and based on larger benthic foraminifera (BouDagher-Fadel, 2018a). In addition, biostratigraphic analyses were performed after a complete inventory of the planktonic foraminiferal taxa in the thin sections, using the zonal scheme and bio-event calibrations from (BouDagher-Fadel, 2018b). The microfacies, fossil content and biostratigraphic characterization of the newly dredged samples are detailed in Table A1. Seismic lines cover most of the GARANTI dredge sites (Figure 2). Once projected on a seismic line, a dredge sample can constrain the age and lithology of the dredged horizon.

\section{Stratigraphic constraints}

Direct stratigraphic constraints on the Grenada Basin are missing because of the lack of deep drilling. IODP drillings (1397 to 1401) west of Martinique (Figure 2) penetrated PlioQuaternary sediments only (Le Friant et al., 2013). However, offshore drill hole data (Bader et al., 1970b; Edgar et al., 1973; Ysaccis, 1997) and onshore geological observations (Speed et al., 1993) in surrounding areas provide distant stratigraphic constraints on deeper units (Figure 3). We tied seismic horizons to known chronostratigraphic surfaces in drill holes, and then extended them line-to-line throughout the basin. Land-sea correlations using outcrops in the Grenadines are more speculative, but they provide valuable information about the age and lithology of seismic units. Section 5.2 gives a detailed description of the seismic units and discontinuities shown in Figure 3.

To constrain the stratigraphy of the Grenada Basin, we have revised the seismic stratigraphy of Aitken et al. (2011) on BOL30 and Gulfrex lines (location in Figure 2) and then extended it to the GARANTI dataset. Based on correlations with wells drilled in the Carúpano Basin (Ysaccis, 1997), these authors divide the southern Grenada Basin into three megasequences (from bottom to top MS1, MS2, and MS3). Megasequence 1 (MS1) includes Paleogene sedimentary rocks, which are predominantly deep-water, pelagic and volcanogenic shale and siltstone, with some banks of pelagic limestone. Megasequence 2 (MS2) is dominated by deep-water turbidites deposited during the Early to Middle Miocene following the onset of transpressional shortening in the southeastern Grenada Basin (Ysaccis, 1997). Megasequence 3 (MS3) contains interbedded pelagic and terrigenous sediments deposited from late Miocene to Recent. In the Carúpano Basin, the boundary between the middle and late Miocene is characterized by an abrupt change from bathyal to neritic environment (Ysaccis, 1997).

The change of depositional setting between the deep Grenada Basin and the elevated Aves Ridge results in significant lateral changes in seismic facies (e.g. GA28A and GA29 in Figure $3)$. To overcome this difficulty in constraining the stratigraphy of Aves Ridge, we used two DSDP sites (30 and 148) that were drilled in its southern part (Figure 2 and Figure 3). As none of our seismic lines covers these sites, we projected the drill holes to the nearest GARANTI lines (GA26A and GA28A in Figure 2). Located in a small basin between two ridges, DSDP 30 penetrated $430 \mathrm{~m}$ of Miocene to Recent calcareous oozes (Bader et al., 1970b). Located atop a ridge, DSDP 148 penetrated $250 \mathrm{~m}$ of Plio-Quaternary calcareous oozes lying unconformably upon volcanic sands and clays, which bear reworked fossils of Miocene, Paleocene, and Late Cretaceous ages (Edgar et al., 1973). It is unclear whether this unconformity results from submarine erosion or subaerial weathering.

As mentioned in section 2.2, previous geophysical studies have suggested that the basement underlying the Grenada Basin is of oceanic origin (Allen et al., 2019; Boynton et al., 1979; Christeson et al., 2008). Speed \& Walker (1991) support this hypothesis by proposing that early-middle Eocene pillow basalts exposed in the Grenadines may be an uplifted portion of the oceanic crust of the Grenada Basin. Based on this assumption, and since the known

This article is protected by copyright. All rights reserved. 
volcanic activity at the Aves Ridge is not older than Late Cretaceous, Aitken et al. (2011) infer a Late Cretaceous to middle Eocene age for the basement of the Grenada Basin, which is consistent with our seismic stratigraphy (Figure 3).

\section{Results}

\subsection{Seismic stratigraphy}

A seismic unit can be defined as a series of conformable reflectors bounded at its top and base by discontinuities and their correlative conformities (Mitchum et al., 1977). Following the principles of seismic sequence stratigraphy defined by Vail et al. (1977) and Catuneanu et al. (2011), we identify one basement unit (U0) and three sedimentary units (U1, U2, U3), each of the first two composed of two subunits (U1a, U1b, U2a, U2b). The units and subunits are separated by discontinuities (D0 to D2b), which can be unconformities or significant vertical changes in seismic facies. Seismic facies may also vary laterally within the same unit. Table A2 summarizes the 16 most representative seismic facies (Fs1 to Fs16).

\subsubsection{U0 - Acoustic basement}

Seismic unit U0 is the deepest unit observed on seismic lines. It is bounded at the top by discontinuity D0, which forms an onlap unconformity for the overlying units. Most lines display a chaotic unit (Fs1 and Fs2 in Table A2) with locally discontinuous internal reflectors of variable amplitude (Fs3 and Fs4 in Table A2). In this paper, U0 is also referred to as the 'acoustic basement' due to its low reflectivity compared with the well-layered overlying units and its high interval velocity (> $5 \mathrm{~km} / \mathrm{s}$ ) as defined from wide-angle seismic data (Padron et al., in press).

On the Aves Ridge, seismic lines oriented NE-SW or NW-SE display layered reflectors within U0 (Fs5 in Table A2). These reflectors are locally truncated or form toplaps under D0, further interpreted as an erosional unconformity named D0 (e.g. GA28A in Figure 3). At the bottom of the slope in the western Grenada Basin, D0 tops thick divergent series of discontinuous east-dipping reflectors (Figure 4a,d).

Every GARANTI line crossing the Grenada Basin displays a transition from rough to smooth basement topography in the center of the basin (Figure 4). East of this transition, the smooth basement morphology is highlighted by high-amplitude, low-frequency reflectors at the top and few internal reflectors below. The rough basement is slightly more reflective with some discontinuous internal reflectors of medium frequency and variable amplitude (F3 and F4 in Table A2). The rough-smooth transition is located around CMP 4000 for line GA21 (Figure 4a), CMP 10500 for GA02 (Figure 4c), CMP 8000 for GA29 (Figure 4d), and appears to be located around CMP 21000 for GA34, although it is partially masked by a blank in seismic acquisition (Figure 4b). Along with the rough-smooth transition, west-dipping reflectors appear 2 to $3 \mathrm{~s}$ twt below D0 (Figure 4). These dipping reflectors coincide with the Moho modeled from wide-angle seismic data along GA02 (Padron et al., in press).

\subsubsection{U1a}

Seismic unit U1a is bounded at the top by discontinuity D1a, which can be either a conformable surface or an onlap unconformity for the overlying units. U1a is characterized by heterogeneous facies, with locally continuous, fan-shaped reflectors (Fs6 in Table A2), which drapes or laps onto the underlying basement. On the Aves Ridge, the uppermost reflectors of U1a are locally truncated or form toplap under the D1a, further interpreted as an erosional

This article is protected by copyright. All rights reserved. 
unconformity named D1a (Figure 5b). U1a lies in isolated basins on the Aves Ridge or in the western Grenada Basin, but is not encountered in the eastern part of the basin where the basement is smoother (Figure 5 and Figure 6). Because of its fan-shaped geometry, we interpret U1a as syn-tectonic deposits. Interval velocity in U1a ranges from 3 to $4 \mathrm{~km} / \mathrm{s}$, which is compatible with compacted sedimentary rocks (Christensen \& Stanley, 2003) . Based on correlations with offshore well data (Figure 3), we may infer that U1a is early Eocene in age.

\subsubsection{U1b}

Seismic unit U1b is bounded at the top by discontinuity D1b, which is an onlap unconformity for the overlying units. In the Grenada Basin, U1b is characterized by one or two pairs of strong, low-frequency reflectors with a positive polarity (Fs7 in Table A2). Reflectors in U1b conformably drape or locally onlap D1a or D0.

In previous studies (Aitken et al., 2011; Pinet et al., 1985), U1b was interpreted as the top of the acoustic basement due to its strong reflectivity and high interval velocity $(4.25$ to $5 \mathrm{~km} / \mathrm{s}$ ). Eocene cherts and cherty carbonates drilled in the Central Venezuelan Basin were attributed to the seismic horizon A" (Bader et al., 1970a), the highly reflective facies of which is similar to U1b. Based on its seismic facies, U1b may be indirectly correlated with the middle Eocene cherts and pelagic limestones identified both in the Grenadines and the Carúpano Basin (Figure 3). Its high interval velocity $(4.25$ to $5 \mathrm{~km} / \mathrm{s}$ ) is compatible with thick-bedded cherts (Fu et al., 2006), but could also represent altered igneous rocks or volcaniclastic deposits.

\subsubsection{U2a}

Seismic unit U2a is bounded at the top by discontinuity D2a, which is a conformable surface or an onlap surface for the overlying units. U2a is mainly characterized by weak, parallel and continuous reflectors (Fs8 in Table A2) that onlap sub-horizontally onto D1b (Figure 5). These onlap patterns contrast sharply with the draping geometry of the underlying U1b deposits.

U2a is equivalent to an upper section of MS1 from Aitken et al. (2011) in terms of age and depositional patterns (comparison in Figure S5). Correlations with offshore well data and onshore geological observations indicate basin floor turbidites with ages ranging from late Eocene to Oligocene (Figure 3). Interval velocity in U2a ranges from 4 to $4.75 \mathrm{~km} / \mathrm{s}$, which is compatible with highly compacted sedimentary rocks (Christensen \& Stanley, 2003).

\subsubsection{U2b}

Seismic unit U2b is bounded at the top by discontinuity D2b, which is a conformable surface or an onlap surface for the overlying unit U3. U2b is deposited conformably within the basin, except on the margins where it locally onlaps onto D2a (Figure 5). Seismic facies in U2b are the same as U2a (Fs8 in Table A2) with slightly higher amplitudes in the uppermost part of the unit. In the eastern Grenada Basin, the reflectors are tilted upwards along the Lesser Antilles arc and the seismic facies becomes increasingly chaotic eastwards (Figure 4; Fs9 in Table A2).

U2b is equivalent to MS2 from Aitken et al. (2011) in terms of age and depositional patterns (comparison in Figure S5). Correlations with offshore well data and onshore geological observations indicate basin floor turbidites with ages ranging from early to middle Miocene (Figure 3). The top of U2b (D2b) is correlated in wells with the boundary between middle and late Miocene (Figure 3). This age coincides with the culmination of oblique collision between the Caribbean Plate and Eastern Venezuela-Trinidad (Pindell \& Kennan, 2007) and also with a major uplift in the Carúpano area (Ysaccis, 1997) and in the southern Lesser Antilles (Speed

This article is protected by copyright. All rights reserved. 
et al., 1993). Interval velocity in U2b ranges from 3 to $4 \mathrm{~km} / \mathrm{s}$, which is compatible with compacted sedimentary rocks (Christensen \& Stanley, 2003).

\subsubsection{U3}

The topmost unit U3 rests conformably or onlaps onto D2b. U3 is mainly characterized by a hummocky pattern with strong, high-frequency reflectors (Fs11 in Table A2) topped by more continuous reflectors (Fs12 in Table A2). As for U2a and U2b, the seismic facies becomes increasingly chaotic in the eastern Grenada Basin (Figure 4; Fs13 in Table A2). Along the Lesser Antilles Arc, reflectors in U3 onlap onto the underlying U2 (Figure 5). From the basin to the Aves Ridge, reflectors in U3 become progressively less continuous and of weaker amplitude (Fs14 in Table A2).

U3 is equivalent to MS3 from Aitken et al. (2011) in terms of age and depositional patterns (comparison in Figure S2). Correlations with wells give ages ranging from late Miocene to recent for U3 (Figure 3). On the Aves Ridge, DSDP drilling results indicate a predominantly hemipelagic calcareous sedimentation with a slight volcaniclastic contribution (Bader et al., 1970b; Edgar et al., 1973). In the Grenada Basin, IODP drillings west of Martinique penetrated landslide deposits, composed of hemipelagic sediments interbedded with volcaniclastics from the Lesser Antilles Arc (Le Friant et al., 2013). Hummocky and chaotic facies often result from mass transport, slump, creep, or high-energy turbidity current processes (Sangree \& Widmier, 1979). Similar facies are also described in recent debris avalanches from the Lesser Antilles Arc deposited in the Grenada Basin (Deplus et al., 2001). Interval velocity in $\mathrm{U} 3$ ranges from 1.5 to $3.5 \mathrm{~km} / \mathrm{s}$, which is compatible with water-saturated to compacted clayey and silty sediments (Schumann et al., 2014).

\subsection{Basin-scale variations in stratigraphy}

Figure 5 illustrates the asymmetric architecture of the Grenada Basin. The basement dips southeastwards and reaches a maximal depth of $17.3 \mathrm{~km}(11 \mathrm{~s}$. twt) in the southeast on line BOL30 (Figure 5 and Figure 6). The sedimentary units form a wedge-shaped infill that thickens as the basement deepens, reaching a maximal thickness of $14.8 \mathrm{~km}(8.5 \mathrm{~s}$. twt) in the southeast on line BOL30 (Figure 5).

Along most of the GARANTI lines, seismic reflectors of units U2-U3 lap onto the edges of the basin (Figure 5), although basinward prograding clinoforms are locally observed, for instance at the foot of Cuervo Peak (Fs10 in Table A2). This indicates that sediment supply was mainly parallel to the basin axis with locally minor prograding systems on the edges. These observations are consistent with those of Aitken et al. (2011) based on BOL30 and other BOLIVAR and Gulfrex lines.

At basin scale, seismic reflectors in $\mathrm{U} 2 \mathrm{a}, \mathrm{U} 2 \mathrm{~b}$, and $\mathrm{U} 3$ are sub-horizontal, except along the Lesser Antilles Arc where they are tilted upwards (Figure 5). This upward tilt gradually increases southwards and is more pronounced in $\mathrm{U} 2 \mathrm{a}$ and $\mathrm{U} 2 \mathrm{~b}$ than in $\mathrm{U} 3$, which results in a sharp angular unconformity between $\mathrm{U} 2 \mathrm{~b}$ and U3 (D2b unconformity in Figure 5). Line GA29 displays another angular unconformity between U2a and U2b (D2a unconformity in Figure 5). Internal angular unconformities are observed within U3 on lines GA29 and GA34 (Figure 5).

Isopach maps (Figure 6) show that U1a is mostly present on the Aves Ridge and along the western margin of the Grenada Basin. Its thickness ranges from 1 to $3.5 \mathrm{~km}$ in basement lows. U1b covers evenly the western part of the Grenada Basin with thicknesses ranging from 0.5 to

This article is protected by copyright. All rights reserved. 
$1 \mathrm{~km}$. South of line GA34, U1b thins progressively eastwards and disappears in the center of the basin (Figure 5 and Figure 6). The depocenter of U1b extends along a northeast-trending axis, parallel to the Aves Ridge flank (Figure 6).

$\mathrm{U} 2 \mathrm{a}, \mathrm{U} 2 \mathrm{~b}$ and $\mathrm{U} 3$ are thicker in the southeastern Grenada Basin, where the basement is deeper (Figure 6d,e,f). The depocenter of U2a has a northeast trend and is located around $62.5^{\circ} \mathrm{W}$ $12.5^{\circ} \mathrm{N}$ (Figure $6 \mathrm{~d}$ ). Its maximum thickness is about $10.85 \mathrm{~km}$ along line BOL30 (Figure 5e). On the Aves Ridge, U2a exists only in small isolated basins and does not exceed $1 \mathrm{~km}$ thick (Figure 6d). Similarly north of $14^{\circ} \mathrm{N}$, its thickness drastically decreases to less than $1 \mathrm{~km}$ (Figure 6d). These strong gradients delineate the edges of a NE-trending late EoceneOligocene basin from 61.5 to $63^{\circ} \mathrm{W}$ and from 12 to $14^{\circ} \mathrm{N}$.

A $100 \mathrm{~km}$ northward migration of depocenter occurred between U2a and U2b (Figure 6e). $\mathrm{U} 2 \mathrm{~b}$ thickness varies from 0.5 to $4 \mathrm{~km}$ in the basin and from 0 to $1.5 \mathrm{~km}$ on the Aves Ridge. To the north, U2b drastically thins between $14.5^{\circ} \mathrm{N}$ and $15^{\circ} \mathrm{N}$. Similarly, U2b pinches out against the northeast-trending eastern flank of the Aves Ridge. These strong gradients delineate the edges of a NNE-trending early-middle Miocene basin from 61.5 to $63^{\circ} \mathrm{W}$ and from 12 to $15^{\circ} \mathrm{N}$.

The depocenter of U3 also trends northeast and reaches a maximum thickness of $2.3 \mathrm{~km}$ in the southwest, about $100 \mathrm{~km}$ southwest of the depocenter of U2b (Figure 6f). A secondary NNWtrending depocenter, with a maximum thickness of $1.5 \mathrm{~km}$, is located around $15^{\circ} \mathrm{N}$ where U2a and $\mathrm{U} 2 \mathrm{~b}$ are very thin. This implies either an additional sediment source that did not exist before U3 or significant subsidence in the northern Grenada Basin between U2b and U3, or a combination of both.

\subsection{Interpreted structural styles and lateral variations}

From the Aves Ridge to the Grenada Basin, tectonic deformation significantly varies. In the following paragraphs, we describe the different types of structure that we have identified on the GARANTI seismic lines

\subsubsection{Rift structures}

Northwest of the Grenada Basin, line GA35 shows a south-dipping normal fault that tilts northwards fan-shaped reflectors within U0 (Figure 7a). The fault barely affects D0, on which the units U1a, U1b, and U2b onlap without deformation. Such geometry suggests tilted block faulting in the acoustic basement. Similar structures are observed in the basin between 15 and $16^{\circ} \mathrm{N}$ and also in the eastern part of Aves Ridge, as on line GA32 (Figure 7b). On this line, reflectors in U1a form a slight fan at its base, although the fault appears to be sealed by D0.

In the eastern part of Aves Ridge, line GA02 displays a series of basement highs and lows bounded by steep planes that shift vertically D0 and the reflectors of U1a (Figure 7c). Within the grabens, east-dipping basement top and fan-shaped reflectors for unit U1a indicate that west-dipping, high-angle normal faults mostly control this horst and graben structure. The easternmost horst defines a basement ridge that culminates along the escarpment between the Aves Ridge and the Grenada Basin, for instance along lines GA29 and GA34 (Figure 5). This discontinuous ridge, which extends at least from line GA28A in the south to GA34 in the north, is observed on every line and is particularly pronounced on GA26B where it forms the Cuervo Peak (Figure 2).

This article is protected by copyright. All rights reserved. 


\subsubsection{Tectonic inversion}

Lines GA25AB and GA34 show a large positive structure between CMP 4200 and 5000 and between CMP 24800 and 25600 respectively (Figure 7d,e). This positive structure forms a bathymetric relief named Petrel Ridge (Figure 2). The structure consists of a series of westdipping normal faults that affect sub-unit U1a, in which gently folded, fan-shaped reflectors are truncated at the top forming the erosional unconformity D1 $\mathrm{a}_{\mathrm{e}}$ (Figure $7 \mathrm{~d}, \mathrm{e}$ ). U1b and U2a are lacking above this surface, so that U2b laps directly onto D1 $a_{e}$ (Figure 7d,e). Since this structure is positive and U1a is folded, the faults were probably reactivated in moderate compression after the deposition of U1a.

To the northeast, line GA21 shows a different type of positive structure between CMP 4000 and 5500 (Figure 5a). It consists of a series of high-angle faults, which are organized into a flower structure at CMP 4000. This flower structure separates a region with a smooth basement and seafloor to the east from one with rougher basement and seafloor to the west. In the latter, the seafloor roughness is mainly related to closely spaced polygonal faults, which affect the upper sedimentary units (predominantly U3, more rarely U2b) and locally outcrop at the surface (Figure 4a and Figure 5a).

\subsubsection{Oceanic crust}

Along line GA02, U1a disappears and the basement topography becomes smoother and less reflective east of CMP 10500 (Figure 7f). High-amplitude, low-frequency reflectors of U1b directly overlay U0 (Figure 7f). This smoother basement topography coincides with the oceanic crust identified in wide-angle data along line GA02 (Padron et al., in press). The westward dipping reflectors imaged between CMP 1.5 to 2.5 stwt below D0 match the oceanic Moho from WAS data (Figure 4f). These Moho reflectors are also observed on GA21, GA34, and GA29 (Figure 4a,b,d respectively).

\subsubsection{Buried volcanoes}

In the western and northern parts of the Grenada Basin, several mound-shaped basement structures between 2 and $6 \mathrm{~km}$ wide are observed 0.5 to $1 \mathrm{~s}$ twt below the seafloor (Figure 8). They are asymmetric with more or less continuous, divergent intra-basement reflectors tilted away from their summit on both sides (Figure 8). We interpret these structures as buried volcanoes, because of their geometric similarity to the buried Kora volcano described by Bischoff et al. (2017) in the Taranaki Basin, offshore New Zealand. The tilted reflectors may be lava or pyroclastic flows on the flanks (Figure 8). On GA31, the sedimentary units lap subhorizontally onto the flanks of the volcano, except U1a which is slightly tilted upwards and is hardly distinguishable from the basement reflectors (Figure 8). This suggests that U1a was deposited during the late stage of volcanic activity or during the early stage of post-magmatic erosion of the volcanic system.

Line GA04 shows a volcanic edifice that has a sharper shape than that observed on GA31 (Figure 8). The volcanic core is recognizable by its transparent facies in the central part (Figure 8). U1b is tilted upwards along both sides of the volcano, conformably draping the underlying tilted reflectors interpreted as lava flows (GA04 in Figure 8). This suggests that U1b could be lava flows as well, which would imply that the volcano would have been active in the middle Eocene. U2b is also tilted upwards and pinches out onto D1b (GA04 in Figure 8). Such upturned pinchouts against angular unconformities are typically part of the postmagmatic degradational sequence (Bischoff et al., 2017).

This article is protected by copyright. All rights reserved. 


\subsection{Drowned carbonate platforms on the Aves Ridge}

\subsubsection{Seismic facies and dredge samples}

Seismic lines covering the Aves Ridge display parallel, low-frequency, strong reflectors atop bathymetric highs (Fs15 in Table A2). This seismic facies characterizes middle Eocene to middle Miocene (U1b-U2b) carbonate platforms that were dredged during GARANTI (Table A1) and previous cruises (Bouysse et al., 1985; Fox et al., 1971; Marlowe, 1971). The GARANTI samples described in Table A1 were dredged from 670 to $2385 \mathrm{~m}$ deep. They are predominantly Aquitanian (23.04-20.44 Ma, i.e. included in U2b) and attributed to reef or inner ramp environments (paleodepth $=0-20 \mathrm{~m}$ ). Some of these samples show evidences of short phases of emersion (DR-GA-05-01-04A and DR-GA-06-02-02 on Fregata Ridge; DRGA-07-02-01, DR-GA-08-01C and DR-GA-08-01D on Cuervo Peak; locations in Figure 2), which are yet to be confirmed by further analyses. One older sample (DR-GA-08-02-01A) yields a Bartonian-Priabonian age (39.2-33.9 Ma) and is attributed to a middle ramp environment (paleodepth $=20-100 \mathrm{~m}$ ). All the samples younger than early Miocene are attributed to deeper environments ranging from outer ramp to basin (paleodepth $>100 \mathrm{~m}$ ).

\subsubsection{Subsidence}

Subsidence of Aves Ridge can be estimated from dredge samples (Figure 2 and Table A1) and seismic interpretation of carbonate platforms. We assume that these carbonate platforms developed on the flanks and tops of subsiding islands, which remained shallow enough to allow the growth of coral reefs. As long as reef building was compensating subsidence, the top of the carbonate platforms was sustained at a relatively constant shallow depth. Following this logic, the thickness of each carbonate sequence, which is estimated from MCS data, can be converted to an amount of subsidence over a period of time. The current depth equates the amount of subsidence that the platform has undergone since reef building ceased. Due to the absence of stylolites and other pressure-dissolution features in the dredge samples, we assume that the carbonates did not undergo any compaction following their formation. The observed carbonate thicknesses can therefore be used as they stand. Based on seismic resolution, we assess a $\pm 100 \mathrm{~m}$ uncertainty in thickness estimation. It must be noted that this approach does not allow us to calculate amounts of uplift, since we cannot estimate the amount of material that would have emerged and been eroded.

Figure 9 illustrates the subsidence at different seamounts, ridges, and escarpments on the Aves Ridge. Most of these sites were dredged during the GARANTI cruise, except the Pelicano seamount. For this one, we used dredge results from previous studies (Bouysse et al., 1985; Marlowe, 1971) to constrain the age of the carbonate sequences. Alcatraz seamount is the only site without MCS data. We infer the thickness of its carbonate sequences from the neighbouring Pelicano seamount.

From early Eocene to the end of middle Eocene ( 56-38 Ma), all the sites subside uniformly and the differences between them are within the error range (Figure 9). From late Eocene to Oligocene $(\sim 38-23 \mathrm{Ma})$, the subsidence rate decreases at all sites from 0.02-0.03 to 0.01 $\mathrm{mm} / \mathrm{yr}$ (Figure 9b).

From early to middle Miocene ( 23-12 Ma), subsidence is slightly greater than in the previous periods and the differences between sites remain within the error range (Figure 9). Since subsidence tends to increase over this period, the phases of emersion suspected from the GARANTI samples of Aquitanian ages (23.03-20.44 Ma) are more likely to be explained by sea-level variations.

This article is protected by copyright. All rights reserved. 
From late Miocene to present ( 12-0 Ma), subsidence differs significantly between the sites (Figure 9), which are now found at various depths. Over this period, subsidence has remained nearly constant at Pelicano and Alcatraz, while it has slightly accelerated at both Fregata sites (increase from 0.02 up to $0.04 \mathrm{~mm} / \mathrm{yr}$ ) and even greater and faster at both Cuervo sites (increase from 0.02 up to $0.1 \mathrm{~mm} / \mathrm{yr}$ ). Such differences may be explained by a southeastward regional tilting, possibly in response to sediment loading in the basin. The vertical offset of $\sim 600 \mathrm{~m}$ between the two Cuervo sites is probably the result of differential subsidence along the normal faults fringing the peak (Figure $5 \mathrm{~d}$ ).

\section{Discussion}

\subsection{Structural domains}

The analysis of the GARANTI seismic data allows us to divide the Grenada Basin and its margins into four distinct structural domains (Figure 10), hereinafter referred to as the 'oceanic domain', the 'transitional domain', the 'Aves Ridge' and the 'Lesser Antilles Arc'. Figure 10 also includes a mapping of the interpreted faults. Fault orientations are deduced from line-to-line correlations or, where it is not possible, from bathymetry.

\subsubsection{Oceanic domain}

Previous geophysical surveys have shown that the Grenada Basin is likely to be partly floored by oceanic crust (Allen et al., 2019; Boynton et al., 1979; Christeson et al., 2008). The GARANTI seismic data confirm the presence of oceanic crust and allow the constraint of its lateral extent.

Wide-angle seismic (WAS) data along line GA02 reveal a 6.5 to $7 \mathrm{~km}$-thick crust with a typical oceanic velocity structure underlying the Grenada Basin, over a width of $80 \mathrm{~km}$ (Padron et al., in press). Christeson et al. (2008) and Allen et al. (2019) also propose a basement of oceanic origin in the southeastern Grenada Basin, based on WAS data along lines BOL30 and VOILA-4 respectively.

In MCS data, the oceanic basement is a chaotic unit with few internal reflectors locally topped by smooth, low-frequency reflectors of U1b (Figure 4 and Figure 7f). Here, we use this seismic facies and shallow Moho reflectors (Figure 4 and Figure 7f) as criteria to define the extent of the oceanic domain.

Combining all evidence, we can outline an oceanic domain extending across the eastern Grenada Basin from $\sim 12^{\circ} \mathrm{N}$ to $15.2^{\circ} \mathrm{N}$ and from 61.5 to $62.5^{\circ} \mathrm{W}$ (Figure 10). This area, which extends as far north as Dominica, appears consistent with previous interpretation of magnetic anomalies (Allen et al., 2019; Bird et al., 1993). The absence of transitional domain between the oceanic domain and the Lesser Antilles suggests that the oceanic crust extends beneath the southern Lesser Antilles Arc, as suggested by previous geophysical studies (Allen et al., 2019; Christeson et al., 2008).

\subsubsection{Transitional domain}

Along line GA02, based on WAS data crustal thinning takes place in a $\sim 100 \mathrm{~km}$ wide transition zone between the $25 \mathrm{~km}$-thick Aves Ridge crust and the 6.5-7 km-thick oceanic crust (Padron et al., in press). The change in velocity structure at the boundary from oceanic to transitional basement coincides with a significant change in seismic facies (Figure 4 and Figure 7f).

This article is protected by copyright. All rights reserved. 
From MCS data, the transitional basement can be characterized by 1) the presence of faults, which produce a rough morphology (Figure 5); 2) discontinuous internal reflectors of variable amplitude (F3 and F4 in Table A2); 3) last occurence of syn-tectonic deposits from unit U1a (Figure 5 and Figure 7). It forms a $\sim 100 \mathrm{~km}$ wide transitional domain between the oceanic crust and the eastern flank of the Aves Ridge from 12 to $14.5^{\circ} \mathrm{N}$, then widens northwards to fully encompass the northern part of the Grenada Basin (blue-gray area in Figure 10).

Line GA04 (the latitude of Dominica) roughly marks the boundary between the deep Grenada Basin to the south and a region of shallower, rougher bathymetry to the north (Figure 2). At crustal scale, the boundary is more diffuse, as the crust gradually thickens northwards (Padron et al., in press). For this reason, we include this area in the transitional domain (Figure 10).

Line-to-line correlations reveal three major fault orientations in the transitional domain: $\sim \mathrm{N} 50-60$ (black faults ' $\mathrm{F} 1$ ' in Figure 10), N0 (blue faults 'F2' in Figure 10), N20-30 (orange faults 'F3' in Figure 10). Faults F1 are normal faults that mostly affect U0 and, to a lesser extent, U1a (Figure 7a,b), thus reflecting a NW-SE extension from the Paleocene to the early Eocene. They define a rifted margin in the northern Grenada Basin and along the eastern flank of the Aves Ridge. The orientations of faults F1 are consistent with those involved in the N-S opening models for the Grenada Basin by Pindell \& Barrett (1990) and Pindell \& Kennan (2009). They are also consistent with the faults previously mapped west of Dominica and Guadeloupe (Speed \& Westbrook, 1984).

Faults F2 are also normal faults, but with a different orientation ( N0, Figure 10) and steeper dips (Figure 7c). Fan-shaped reflectors of U1a in the Pelicano graben (Figure 7c) indicate that these faults were active during the early Eocene. Faults F2 are parallel to the ridge crests supposed to have hosted the volcanic arc of the Aves Ridge (Figure 2 and Figure 10). Thus, they could have been inherited from the period of arc volcanism on Aves Ridge (CretaceousPaleocene) and would have been reactivated in the early Eocene. The same trend can be found in bathymetry along the southeastern flank of the Aves Ridge, between $12^{\circ} \mathrm{N}$ and $13^{\circ} \mathrm{N}$ (dotted lines in Figure 10; original data in Figure 2), thus suggesting a pre-rift structuring of the margin.

Faults F3 include various types of compressional and transpressional structures (thrust faults, folds, inverted normal faults, positive flower structures), which reflect a phase of tectonic inversion. Some of these faults were extensional during the Paleocene-early Eocene and were reactivated into compression (Figure 7d,e). Aitken et al. (2011) have already described this inversion, as it is well expressed on line BOL30 (Figure 5e). These authors have dated the onset of the inversion around the Oligocene-Miocene boundary, which is consistent with our data. Further north, the inversion is observed only in specific places (Figure 5a, Figure 7d,e).

Buried volcanic systems are observed throughout the transitional domain, especially north of $15^{\circ} \mathrm{N}$ (Figure 8 and Figure 10). Their stratigraphic relationship with the sedimentary units suggests a diachronous volcanism from southwest to northeast (Figure 8). In the western part of the Grenada Basin, volcanism could have been active during the deposition of U1a (Early Eocene) or earlier (GA31 in Figure 8). North of $15^{\circ} \mathrm{N}$, volcanism occurred later, probably in the middle Eocene (GA04 in Figure 8). Arnaiz-Rodríguez \& Audemard (2018) propose that the rough basement of the northern Grenada Basin (north of $15^{\circ} \mathrm{N}$ ) results from Paleogene magmatic intrusions above a slowly retreating slab. The northeast decreasing age of the volcanic intrusions could therefore reflect a gradual migration in arc magmatism before the slab reached a stable position enabling the initiation of the Lesser Antilles Arc. A second hypothesis would be breakup-related volcanism during the onset of seafloor spreading. As arc magmatism already started on St Barthelemy Island (outer Lesser Antilles) during the middle Eocene (Legendre et al., 2018), we favor this latter hypothesis.

This article is protected by copyright. All rights reserved. 


\subsubsection{Aves Ridge}

It is widely accepted that the Aves Ridge is a remnant arc, yet little evidence supports this hypothesis (Bouysse et al., 1985; Fox et al., 1971; Nagle, 1972). WAS data along lines GA02 (Padron et al., in press) and BOL30 (Christeson et al., 2008) reveal a $25 \mathrm{~km}$-thick crust underlying the Aves Ridge, the velocity structure of which is compatible with an arc origin.

At the foot of the eastern flank of the Aves Ridge, the rough basement morphology tops thick divergent series of discontinuous reflectors dipping towards the oceanic basin along GA21 (Figure $4 \mathrm{a}$ and Figure 5a). These dipping reflectors could be lava flows or volcaniclastics related to the Aves Ridge or younger syn-rift volcanic edifices, such as that observed on line GA31 (Figure 8). Alternatively, the dipping reflectors observed along the eastern flank of the Aves Ridge could represent an eastern extent of the Caribbean Plateau underlying the volcanic arc crust of the Aves Ridge (Mauffret \& Leroy, 1997).

Intra-basement basinward-dipping reflectors are also observed beneath some bathymetric highs, such as Cuervo Peak (Figure 4d and Figure 5d). We cannot exclude a volcanic origin for these highs, although only carbonates were dredged from their cliffs (Table A1).

\subsubsection{Southern Lesser Antilles Arc}

The GARANTI seismic data highlight an asymmetrical basin architecture (Figure 5, Figure 6, and Figure 10), which supports the hypothesis that the Grenada Basin originally extended further east and was subsequently divided by the rise of the Lesser Antilles Arc (Aitken et al., 2011; Allen et al., 2019; Speed \& Walker, 1991). The depocenter of U2a (Figure 6d) is compatible with a basin that extended into the current forearc until the Miocene. An extended data set is required to image the eastern margin of this wider proto-basin.

The upward tilt of the sedimentary units along the active arc reflects the uplift of the Lesser Antilles relative to the Grenada Basin (Figure 5). Speed et al. (1993) report that the tectonic uplift of the southern Lesser Antilles platform (Grenada and Grenadines Islands) began around the Oligocene-Miocene boundary, and was completed before the onset of subaerial arc volcanism at $12 \mathrm{Ma}$. This uplift is related to NNW-SSW compression recorded as fold and thrusts in the Grenadines (Speed et al., 1993). The angular unconformity D2a (Figure 5d) is compatible with a tectonic uplift that would have occurred over the same period. This also coincides with the onset of transpressional deformation in the southern Grenada Basin (Aitken et al., 2011). All these elements attest for an episode of tectonic shortening localized in the southeastern Grenada Basin during the late Oligocene-early Miocene. The angular unconformity D2b (Figure 5b,c,d) indicates that the uplift has continued during the Miocene along the entire length of the Lesser Antilles Arc. Since we found no evidence of normal faulting along the western flank of the Lesser Antilles, we assume that this second phase of uplift was mainly driven by the magmatic growth of the arc.

\subsection{Vertical motions along the Aves Ridge}

The broad extent of the erosional unconformity $\mathrm{D} 0$ e (Figure 5) suggests that a large part of Aves Ridge remained above sea level until the Eocene. D0 $0_{\mathrm{e}}$ is observed down to $6 \mathrm{~km}$ deep in the transitional domain (Figure 5), which implies that the eastern flank of the Aves Ridge has undergone considerable subsidence since the Paleocene. The subsidence of the Aves Ridge may have started shortly after the end of arc volcanism at $\sim 59 \mathrm{Ma}$ (J. E. Wright \& Wyld, 2011) during the rifting. Our results show that subsidence remains relatively moderate from the Eocene to the middle Miocene (Figure 9). This allowed the development of carbonate platforms on bathymetric highs throughout the Aves Ridge (Bouysse et al., 1985;

This article is protected by copyright. All rights reserved. 
Fox et al., 1971; Marlowe, 1971; Münch et al., 2019).

The onset of subsidence slowdown (Figure 9b) is synchronous with the late EoceneOligocene compressional uplift that caused the emergence of the so-called 'GrANoLA' landmass (Greater Antilles-Northern Lesser Antilles) (Philippon et al., 2020). This subsidence slowdown also corresponds in time with the late Oligocene-early Miocene tectonic inversion in the Grenada Basin, which preceded the emplacement of the Miocene to Recent southern southern Lesser Antilles Arc (see previous section). This inversion and possible uplift occurred in a time of oblique convergence between the Caribbean and South American Plates (Avé Lallemant, 1997) (see vectors in Figure 11). In our study area, the Petrel Ridge is the only evidence of compression that could have led to an uplift and potential emersion of a small part of the Aves Ridge in the late Oligocene (Figure 7d,e). Although our data suggest that subsidence has been continuous since the middle Eocene (Figure 9), we do not exclude a possible uplift and partial emersion of the Aves Ridge around the late Oligocene-early Miocene boundary.

The late Miocene-Present acceleration in subsidence (Figure 9) has led to the cessation of reef building and thus the drowning of the Aves Ridge. The fact that the acceleration is greater along the southeastern flank (Cuervo) than in the central part (Pelicano) reflects a regional southeastward tilting. This is consistent with the stress relaxation following the change from oblique convergence to strike-slip regime between the Caribbean and South American plates at $\sim 10 \mathrm{Ma}$ (Pindell \& Kennan, 2007) (see vectors in Figure 11). The tilting might be amplified by sediment loading in the basin.

\subsection{Tectonic evolution}

In the following paragraphs, we integrate our results with previous works in order to provide an update of the tectonic evolution of the Grenada Basin. Figure 11 summarizes major tectonic, magmatic, and sedimentary events identified in the GARANTI data and previous studies. Figure 12 illustrates the regional tectonic evolution that we propose from this synthesis.

\subsubsection{Late Cretaceous to Paleocene: pre-rift evolution}

The Caribbean Plateau formed during the Late Cretaceous as a result of two main magmatic events at $\sim 89 \mathrm{Ma}$ and $\sim 75 \mathrm{Ma}$ (Dürkefälden, Hoernle, Hauff, Wartho, et al., 2019; Dürkefälden, Hoernle, Hauff, Werner, et al., 2019). Following the plateau formation, a volcanic arc developed at the Aves Ridge and remained active until $\sim 59 \mathrm{Ma}$ (J. E. Wright \& Wyld, 2011). Dipping reflectors in the acoustic basement (Figure 4a and Figure 5a) may represent lava flows and volcaniclastics produced during these successive magmatic phases, but also during the eruption of younger volcanoes (Figure 8) as rifting ensued just prior to the onset of seafloor spreading. The erosional unconformity $\mathrm{D} 0 \mathrm{e}$ (Figure 5 and Figure 7) and the lack of pre-Eocene sedimentary units suggest that a large part of the Aves Ridge emerged while it was an active arc. The fact that $\mathrm{D} 0_{\mathrm{e}}$ can be traced at great depths along the eastern flank of the present-day ridge (Figure 5) indicates that the ridge extended further east before the opening of the Grenada Basin.

The normal faults F2 might be inherited from the period of arc volcanism on Aves Ridge, as they follow the trend of the supposed remnant arc (Figure 10). We assume that these faults reflect extensional deformation in the past arc and/or forearc, in relation to the past subduction. They were later reactivated during the rifting of the Aves Ridge.

This article is protected by copyright. All rights reserved. 


\subsubsection{Late Paleocene to early Eocene: rifting}

Collision of an arc (here the Great Arc of the Caribbean) with a buoyant crustal body (e.g. Bahamas Bank) can generate rapid forearc rotation leading to back-arc rifting away from the point of collision (van den Broek et al., 2020; Wallace et al., 2009). In this sense, Aitken et al. (2011) mention the collision at the south and north ends of the Great Arc of the Caribbean as a possible mechanism for the acceleration of slab rollback and arc rotation during the Paleocene and Eocene. Slab rollback would have led to the abandonment of the Aves Ridge accompanied by intra-arc extension. Fan-shaped reflectors in U0 (Figure 7a,b) and U1a in grabens (Figure 7c) indicate that extension occurred during the late Paleocene-early Eocene (Figure 11 and Figure 12a).

The normal faults mapped in the Grenada Basin (Figure 10) suggest that the extension was directed NW-SE, i.e. obliquely with respect to the relative motion of the ongoing plate convergence (Figure 11 and Figure 12a). This is consistent with the direction of extension proposed by Pindell \& Barrett (1990) and Pindell \& Kennan (2009). Accounting for the gain of area during rifting and spreading, one may consider that the trench was oriented NE-SW rather than N-S before the opening of the Grenada basin, so that the slab pull might be directed southeastwards.

It has been proposed that slab rollback was faster in the south (Arnaiz-Rodríguez \& Audemard, 2018) due to the formation of a STEP fault at the Caribbean-South American plate boundary (van Benthem et al., 2013). Another possible explanation for the faster southeastern rollback of the South American plate is the fact that the southeastern edge of the Caribbean plate passed over the Guajira-Maracaibo promontory at the end of the Paleocene (Montes et al., 2019; Pindell \& Kennan, 2009).

\subsubsection{Middle Eocene: seafloor spreading}

Continued extension led to accretion of oceanic crust (Figure 12b), at least in the southeastern Grenada Basin. Since U1b seals the deformation in the transitional domain and pinches out in the oceanic domain (Figure 5c,d,e and Figure 6c), its deposition must have been contemporaneous with seafloor spreading. This gives a middle Eocene age ( 48-38 Ma) for the oceanic crust of the Grenada Basin. This age is consistent with that of the middle Eocene pillow basalts of Mayreau, Grenadines Islands (Speed \& Walker, 1991), thus supporting the hypothesis that they are a window of the underlying oceanic basement further uplifted. Consequently, if arc volcanism occurred during seafloor spreading, the arc was possibly located east of the present-day Lesser Antilles, as suggested by Allen et al. (2019). However, it is difficult to validate this hypothesis without direct geological evidence. Arc volcanism also might have been mingled with the rift prior to the spreading phase as in the southern Okinawa Trough (Sibuet et al., 1998), but then it was likely located along the eastern margin of the oceanic basin, i.e., either beneath the active Lesser Antilles Arc or further east. Alternatively, the lacking part of the rifted margin might have moved southwards and been accreted to the Venezuelan margin (Tobago and Margarita terranes) (Pindell \& Kennan, 2009).

The NE-trending termination of U1b deposits in the center of the present-day oceanic basin (Figures 5 and 6c) suggests that the oceanic crust formed by NW-SE seafloor spreading (Figure 12b). Although transform faults are required to fit the geometry of the oceanic domain (Figure 12b), the GARANTI seismic lines show neither spreading center nor transform fault that would provide better constraints on the direction of spreading. However, a reasonable scenario would place the paleo-spreading center east of and parallel to the NE-SW U1b

This article is protected by copyright. All rights reserved. 
deposit. If this was the case, then the total width of the oceanic domain could have reached $150 \mathrm{~km}$ or more instead of the presently observed $80 \mathrm{~km}$ south of $14^{\circ} \mathrm{N}$.

\subsubsection{Late Eocene to Oligocene: post-rift inversion}

From late Eocene to Oligocene, the proto-Orinoco river flowed northwards from western Venezuela into the Caribbean Sea (Díaz de Gamero, 1996). This resulted in the deposition of massive turbidites of U2a in the Grenada Basin (Figure 5). U2a is the first unit to cross the entire basin (Figure 5 and Figure 6), which means that this unit postdates the oceanic spreading. The opening of the Grenada Basin was therefore completed at the beginning of the late Eocene. Thermal subsidence of the newly formed oceanic lithosphere would have created a large available space, which could explain the remarkably great thickness (up to $10.85 \mathrm{~km}$ ) of U2a in the south (Figure 6d). No significant differential motion, out of elastic flexure, occurred between the Aves Ridge and the Grenada Basin since the late Eocene, as U2a and overlying units lap sub-horizontally against the eastern flank of Aves Ridge (Figure 5).

During the late Oligocene (Figure 12c), the oblique convergence between the Caribbean and South American plates (Escalona \& Mann, 2011; Pindell \& Barrett, 1990; Pindell \& Kennan, 2009) caused the onset of transpressional deformation in the southern Grenada Basin (Figure $5 \mathrm{e}$ ) and the tectonic uplift of the southern Lesser Antilles Arc (namely Grenada and Grenadines Islands), as recorded by the angular unconformity D2a (Figure 5d). This, combined with the fact that subduction-related magmatism has been occurring since at least $38 \mathrm{Ma}$ on Grenada (White et al., 2017), means that the separation of the Grenada and Tobago basins began during either the late Eocene or the Oligocene. This transpressional phase also led to the localized tectonic inversion of Petrel Ridge (Figure 7d,e) and other positive structures (Figure 5a). All these events including the cessation of basin opening, the volcanic arc migration, uplift and thrusting, as well as the transpression recorded in the southern Grenada Basin and Petrel Ridge suggest a shallowing of the slab dip (Lallemand et al., 2005) between the middle Eocene and Oligocene up to its current configuration since the position of the arc has not significantly changed since that time.

\subsubsection{Early to middle Miocene: back-arc subsidence}

From early to middle Miocene, the Aves Ridge subsided (Figure 9) along with the Grenada Basin, while the Lesser Antilles Arc continued to grow, as shown by the D2b unconformity (Figure 5). Turbidites of U2b continued to fill the available space, thus extending further north than U2a (Figure 6d,e). U2b was deposited along with ongoing transpressional deformation in the south, which shifted the depocenter $100 \mathrm{~km}$ northwards with respect to U2a (Figure 6d,e). The eastward change in seismic facies along the Lesser Antilles (Figure 4) could reflect the increasing amount of volcaniclastic and/or landslide deposits coming from the arc.

\subsubsection{Late Miocene to Recent: subsidence acceleration and change in sediment source}

From late Miocene to present, subsidence has sharply accelerated, in particular at the southeastern flank of the Aves Ridge (Figure 9), thus leading to the cessation of reef building and the drowning of the Aves Ridge. Over the same period, the Grenada Basin has been isolated from the Orinoco river system following the Miocene uplift of the Venezuelan coastal ranges (Escalona \& Mann, 2011). As a result, seismic unit U3 predominantly consists of pelagic sediments and volcaniclastic deposits coming from the Lesser Antilles Arc.

This article is protected by copyright. All rights reserved. 


\section{Conclusions}

The analysis of the GARANTI MCS data sheds light on basement structure, depositional history, tectonic deformation and vertical motions of the Grenada Basin, thus providing new constraints on its tectonic evolution.

The rifting of the Grenada Basin began during of the Paleocene and oceanic spreading terminated at the end of the middle Eocene. Since then, no significant differential motion occurred between the Aves Ridge and the Grenada Basin. The oceanic domain now encompasses the eastern half of the basin from 12 to at least $14.5^{\circ} \mathrm{N}$. A thicker basement of possibly oceanic nature extends up to $15.5^{\circ} \mathrm{N}$.

The Grenada Basin is highly asymmetrical, both in terms of basement morphology and sedimentary architecture. Our data support the hypothesis that the Grenada Basin originally extended beneath the present-day southern Lesser Antilles Arc and probably partly into the present-day Tobago Basin (Speed \& Walker, 1991). This wider proto-basin was subsequently divided by the rise of the Lesser Antilles Arc. The separation between the Grenada and Tobago basins began during the late Eocene or the Oligocene, probably in response to a decrease in slab dip and compression originating either from the subducting oceanic plate or from the interaction with South America.

The Aves Ridge has subsided almost continuously along with the Grenada Basin since at least the middle Eocene. The late Oligocene subsidence slowdown is coincident with tectonic inversion in the Grenada Basin. The late Miocene-Present subsidence acceleration coincides with the change from oblique collision to strike-slip along the plate boundary (Pindell \& Kennan, 2007) and may have been amplified by sediment loading in the basin.

We have refined and expanded Grenada Basin opening models from previous studies by 1) better outlining the oceanic and transitional domains in the Grenada Basin and confirming that the oceanic domain extends beneath the southern Lesser Antilles Arc, 2) refining the understanding of the tectono-magmatic evolution, 3 ) finding evidence for syn-rifting and synspreading volcanic activity in the western and northern Grenada Basin. Further investigations are needed to characterize these volcanic products, find relics of the middle Eocene Arc south of Martinique Island and better constrain the location and azimuth of paleo-spreading centers and hypothetical transform faults.

\section{Data availability}

The data acquired during the GARANTI cruise are available at SISMER in the GARANTI cruise repository: https://doi.org/10.17600/17001200

\section{Acknowledgments}

We gratefully thank the captain and crew of $R / V$ L'Atalante, as well as the technical staff of Genavir and Geoazur for having successfully completed the acquisition of seismic data and dredge samples during the GARANTI cruise. We acknowledge the ANR-17-CE31-0009 GAARANTI project for funding Clément Garrocq's PhD fellowship. The CNRS-INSU funded travel for the cruise participants and a post-cruise meeting. We thank Paul Mann, Christophe Basile, Gilles Merzeraud, Laurent Husson, Nestor Cerpa, and Rodolphe Cattin for

This article is protected by copyright. All rights reserved. 
insightful discussions on seismic interpretation and Caribbean geodynamics. Special thanks to Alison Chalm for revising the English and Anne Delplanque for assistance in figure preparation. We thank the two reviewers Jim Pindell and Jenny Collier and the associate editor Gail Christeson for their constructive comments that helped to improve the manuscript.

The GARANTI cruise team includes Jean-Frédéric Lebrun, Serge Lallemand, Arnaud Agranier, Diane Arcay, Franck Audemard, Marie-Odile Beslier, Milton Boucard, JeanJacques Cornée, Maud Fabre, Aurélien Gay, David Graindorge, Arnauld Heuret, Frauke Klingelhoefer, Mireille Laigle, Jean-Len Léticée, Deny Malengros, Boris Marcaillou, Bernard Mercier de Lepinay, Philippe Münch, Emilien Oliot, Davide Oregioni, Crelia Padron, Mélody Philippon, Frédéric Quillévéré, Gueorgui Ratzov, Laure Schenini, Ben Yates.

Seismic data processing used SolidQC developed by Ifremer and the Geovation software developed by CGG. Seismic horizon picking, isopach maps, and fault interpretation were made using the Kingdom software developed by IHS. The figures were drafted using Seismic Unix, GMT, Qgis, and Adobe Illustrator softwares.

\section{References}

Aitken, T., Mann, P., Escalona, A., \& Christeson, G. (2011). Evolution of the Grenada and Tobago basins and implications for arc migration. Marine and Petroleum Geology, 28(1), 235-258. https://doi.org/10.1016/j.marpetgeo.2009.10.003

Allen, R. W., Collier, J. S., Stewart, A. G., Henstock, T., Goes, S., \& Rietbrock, A. (2019). The role of arc migration in the development of the Lesser Antilles: A new tectonic model for the Cenozoic evolution of the eastern Caribbean. Geology, 47(9), 891-895. https://doi.org/10.1130/G46708.1

Andreieff, P., Westercamp, D., Garrabé, F., Bonneton, J. R., \& Dagain, J. (1988). Stratigraphie de l'île de Saint-Martin, (Petites Antilles septentrionales). Géologie de la France, 2-3, 71-88.

Arnaiz-Rodríguez, M. S., \& Audemard, F. (2018). Isostasy of the Aves Ridge and neighbouring basins. Geophysical Journal International, 215(3), 2183-2197. https://doi.org/10.1093/gji/ggy401

Avé Lallemant, H. G. (1997). Transpression, displacement partitioning, and exhumation in the eastern Caribbean / South American plate boundary zone. Tectonics, 16(2), 272-289. https://doi.org/10.1029/96TC03725

Babb, S., \& Mann, P. (1999). Chapter 18 Structural and sedimentary development of a neogene transpressional plate boundary between the caribbean and South America plates in Trinidad and the Gulf of paria. In P. Mann (Ed.), Sedimentary Basins of the World (Vol. 4, pp. 495-557). Elsevier. https://doi.org/10.1016/S1874-5997(99)800525

Bader, R. G., Gerard, R. D., Benson, W. E., Bolli, H. M., Hay, W. W., Rothwell, W. T. Jr., et al. (1970a). Site 29 (Deep Sea Drilling Project Initial Reports No. 4-29) (p. 68). Washington, D. C. doi:10.2973/dsdp.proc.4.108.1970

Bader, R. G., Gerard, R. D., Benson, W. E., Bolli, H. M., Hay, W. W., Rothwell, W. T. Jr., et al. (1970b). Site 30 (Deep Sea Drilling Project Initial Reports No. 4-30) (p. 27). Washington, D. C. doi:10.2973/dsdp.proc.4.109.1970

Bird, D. E., Hall, S. A., Casey, J. F., \& Millegan, P. S. (1993). Interpretation of magnetic anomalies over the Grenada Basin. Tectonics, 12(5), 1267-1279. https://doi.org/10.1029/93TC01185

Bird, D. E., Hall, S. A., Casey, J. F., \& Millegan, P. S. (1999). Chapter 15 Tectonic evolution

This article is protected by copyright. All rights reserved. 
of the grenada basin. In P. Mann (Ed.), Sedimentary Basins of the World (Vol. 4, pp. 389-416). Elsevier. https://doi.org/10.1016/S1874-5997(99)80049-5

Bischoff, A. P., Nicol, A., \& Beggs, M. (2017). Stratigraphy of architectural elements in a buried volcanic system and implications for hydrocarbon exploration. Interpretation, 5(3), SK141-SK159. https://doi.org/10.1190/INT-2016-0201.1

Boschman, L. M., van Hinsbergen, D., Torsvik, T. H., Spakman, W., \& Pindell, J. L. (2014). Kinematic reconstruction of the Caribbean region since the Early Jurassic. EarthScience Reviews, 138, 102-136. https://doi.org/10.1016/j.earscirev.2014.08.007

BouDagher-Fadel, M. K. (2018a). Evolution and Geological Significance of Larger Benthic Foraminifera, Second Edition. UCL Press.

BouDagher-Fadel, M. K. (2018b). Revised diagnostic first and last occurrences of Mesozoic and Cenozoic planktonic foraminifera. UCL Office of the Vice-Provost Research, Professional Papers Series, (2), 1-5.

Bouysse, P. (1984). 7. The Lesser Antilles Island Arc: Structure and Geodynamic Evolution. In B. Biju-Duval, Initial Reports of the Deep Sea Drilling Project, 78A.

Bouysse, P. (1988). Opening of the Grenada back-arc Basin and evolution of the Caribbean plate during the Mesozoic and early Paleogene. Tectonophysics, 149(1), 121-143. https://doi.org/10.1016/0040-1951(88)90122-9

Bouysse, P., \& Guennoc, P. (1983). Donnees sur la structure de l'arc insulaire des Petites Antilles, entre Ste-Lucie et Anguilla. Marine Geology, 53(1), 131-166. https://doi.org/10.1016/0025-3227(83)90038-5

Bouysse, P., Andreieff, P., Richard, M., Baudron, J. C., Mascle, A., Maury, R. C., \& Westercamp, D. (1985). Aves Swell and Northern Lesser Antilles Ridge: rockdredging results from ARCANTE 3 cruise (pp. 67-76). Presented at the Géodynamique des Caraïbes, Paris: Editions Technip.

Boynton, C. H., Westbrook, G. K., Bott, M. H. P., \& Long, R. E. (1979). A seismic refraction investigation of crustal structure beneath the Lesser Antilles island arc. Geophysical Journal of the Royal Astronomical Society, 58(2), 371-393. https://doi.org/10.1111/j.1365-246X.1979.tb01031.x

Briden, J. C., Rex, D. C., Faller, A. M., Tomblin, J. F., \& Brown, G. M. (1979). K-Ar geochronology and palaeomagnetism of volcanic rocks in the Lesser Antilles island arc. Philosophical Transactions of the Royal Society of London. Series A, Mathematical and Physical Sciences, 291(1383), 485-528. https://doi.org/10.1098/rsta.1979.0040

van den Broek, J. M., Magni, V., Gaina, C., \& Buiter, S. J. H. (2020). The Formation of Continental Fragments in Subduction Settings: The Importance of Structural Inheritance and Subduction System Dynamics. Journal of Geophysical Research: Solid Earth, 125(1), e2019JB018370. https://doi.org/10.1029/2019JB018370

Burke, K. (1988). Tectonic Evolution of the Caribbean. Annual Review of Earth and Planetary Sciences, 16(1), 201-230. https://doi.org/10.1146/annurev.ea.16.050188.001221

Catuneanu, O., Galloway, W. E., Kendall, C. G. S. t C., Miall, A. D., Posamentier, H. W., Strasser, A., \& Tucker, M. E. (2011). Sequence Stratigraphy: Methodology and Nomenclature. Newsletters on Stratigraphy, 173-245. https://doi.org/10.1127/00780421/2011/0011

Christensen, N. I., \& Stanley, D. (2003). Seismic Velocities and Densities of Rocks. In W. H. K. Lee, H. Kanamori, P. C. Jennings, \& C. Kisslinger (Eds.), International Geophysics (Vol. 81, pp. 1587-1594). Academic Press. https://doi.org/10.1016/S00746142(03)80278-4

Christeson, G. L., Mann, P., Escalona, A., \& Aitken, T. J. (2008). Crustal structure of the

This article is protected by copyright. All rights reserved. 
Caribbean-northeastern South America arc-continent collision zone. Journal of

Geophysical Research: Solid Earth, 113(B8). https://doi.org/10.1029/2007JB005373

Clark, S. A., Sobiesiak, M., Zelt, C. A., Magnani, M. B., Miller, M. S., Bezada, M. J., \& Levander, A. (2008). Identification and tectonic implications of a tear in the South American plate at the southern end of the Lesser Antilles. Geochemistry, Geophysics, Geosystems, 9(11). https://doi.org/10.1029/2008GC002084

Clark, T. F., Korgen, B. J., \& Best, D. M. (1978). Heat flow in the eastern Caribbean. Journal of Geophysical Research: Solid Earth, 83(B12), 5883-5891. https://doi.org/10.1029/JB083iB12p05883

Corsini, M., Lardeaux, J. M., Verati, C., Voitus, E., \& Balagne, M. (2011). Discovery of Lower Cretaceous synmetamorphic thrust tectonics in French Lesser Antilles (La Désirade Island, Guadeloupe): Implications for Caribbean geodynamics. Tectonics, 30(4), n/a-n/a. https://doi.org/10.1029/2011TC002875

DeMets, C., Jansma, P. E., Mattioli, G. S., Dixon, T. H., Farina, F., Bilham, R., et al. (2000). GPS geodetic constraints on Caribbean-North America Plate Motion. Geophysical Research Letters, 27(3), 437-440. https://doi.org/10.1029/1999GL005436

Deplus, C., Le Friant, A., Boudon, G., Komorowski, J.-C., Villemant, B., Harford, C., et al. (2001). Submarine evidence for large-scale debris avalanches in the Lesser Antilles Arc. Earth and Planetary Science Letters, 192, 145-157. https://doi.org/10.1016/S0012-821X(01)00444-7

Dewey, J. F. (1980). Episodicity, sequence and style at convergent plate boundaries. In D. W. Strangway (Ed.), The Continental Crust and Its Mineral Deposits (Vol. 20). Geological Association of Canada.

Díaz de Gamero, M. L. (1996). The changing course of the Orinoco River during the Neogene: a review. Palaeogeography, Palaeoclimatology, Palaeoecology, 123(1), 385-402. https://doi.org/10.1016/0031-0182(96)00115-0

Donnelly, T. W. (1975). The Geological Evolution of the Caribbean and Gulf of MexicoSome Critical Problems and Areas. In A. E. M. Nairn \& F. G. Stehli (Eds.), The Gulf of Mexico and the Caribbean (pp. 663-689). Boston, MA: Springer US. https://doi.org/10.1007/978-1-4684-8535-6_15

Dürkefälden, A., Hoernle, K., Hauff, F., Wartho, J.-A., van den Bogaard, P., \& Werner, R. (2019). Age and geochemistry of the Beata Ridge: Primary formation during the main phase ( 89 Ma) of the Caribbean Large Igneous Province. Lithos, 328-329, 69-87. https://doi.org/10.1016/j.lithos.2018.12.021

Dürkefälden, A., Hoernle, K., Hauff, F., Werner, R., \& Garbe-Schönberg, D. (2019). Secondstage Caribbean Large Igneous Province volcanism: The depleted Icing on the enriched Cake. Chemical Geology, 509, 45-63. https://doi.org/10.1016/j.chemgeo.2019.01.004

Edgar, N. T., Saunders, J. B., Donnelly, T. W., Schneidermann, N., Maurasse, F., Bolli, H. M., et al. (1973). Site 148 (Deep Sea Drilling Project Initial Reports No. 15-148) (p. 59). Washington, D. C. doi:10.2973/dsdp.proc.15.104.1973

Escalona, A., \& Mann, P. (2011). Tectonics, basin subsidence mechanisms, and paleogeography of the Caribbean-South American plate boundary zone. Marine and Petroleum Geology, 28(1), 8-39. https://doi.org/10.1016/j.marpetgeo.2010.01.016

Fox, P. J., Schreiber, E., \& Heezen, B. C. (1971). The geology of the Caribbean crust: Tertiary sediments, granitic and basic rocks from the Aves ridge. Tectonophysics, 12(2), 89-109. https://doi.org/10.1016/0040-1951(71)90011-4

Fu, D. (Taller), Sullivan, E. C., \& Marfurt, K. J. (2006). Rock property- and seismic-attribute analysis of a chert reservoir in the Devonian Thirty-one Formation, west Texas, U.S.A.Devonian chert in west Texas. Geophysics, 71(5), B151-B158.

This article is protected by copyright. All rights reserved. 
https://doi.org/10.1190/1.2335636

Germa, A., Quidelleur, X., Labanieh, S., Chauvel, C., \& Lahitte, P. (2011). The volcanic evolution of Martinique Island: Insights from K-Ar dating into the Lesser Antilles arc migration since the Oligocene. Journal of Volcanology and Geothermal Research, 208(3), 122-135. https://doi.org/10.1016/j.jvolgeores.2011.09.007

Govers, R., \& Wortel, M. J. R. (2005). Lithosphere tearing at STEP faults: response to edges of subduction zones. Earth and Planetary Science Letters, 236(1), 505-523. https://doi.org/10.1016/j.eps1.2005.03.022

Holcombe, T. L., Ladd, J. W., Westbrook, G. K., Edgar, N. T., \& Bowland, C. L. (1990). 9. Caribbean marine geology; Ridges and basins of the plate interior. In The Caribbean Region.

Honza, E. (1995). Spreading mode of backarc basins in the western Pacific. Tectonophysics, 251(1), 139-152. https://doi.org/10.1016/0040-1951(95)00054-2

Iturralde-Vinent, M., \& MacPhee, R. D. E. (1999). Paleogeography of the Caribbean region : implications for Cenozoic biogeography. Bulletin of the AMNH : no. 238.

Iturralde-Vinent, M. A., García-Casco, A., Rojas-Agramonte, Y., Proenza, J. A., Murphy, J. B., \& Stern, R. J. (2016). The geology of Cuba: A brief overview and synthesis. GSA TODAY, 26(10), 4-10. https://doi.org/10.1130/GSATG296A.1

Jolly, W. T., Lidiak, E. G., \& Dickin, A. P. (2008). Bimodal volcanism in northeast Puerto Rico and the Virgin Islands (Greater Antilles Island Arc): Genetic links with Cretaceous subduction of the mid-Atlantic ridge Caribbean spur. Lithos, 103(3), 393414. https://doi.org/10.1016/j.lithos.2007.10.008

Jouanne, F., Audemard, F. A., Beck, C., Van Welden, A., Ollarves, R., \& Reinoza, C. (2011). Present-day deformation along the El Pilar Fault in eastern Venezuela: Evidence of creep along a major transform boundary. Journal of Geodynamics, 51(5), 398-410. https://doi.org/10.1016/j.jog.2010.11.003

Karig, D. E. (1972). Remnant Arcs. GSA Bulletin, 83(4), 1057-1068. https://doi.org/10.1130/0016-7606(1972)83[1057:RA]2.0.CO;2

Kearey, P. (1974). Gravity and Seismic Reflection Investigations into the Crustal Structure of the Aves Ridge, Eastern Caribbean. Geophysical Journal of the Royal Astronomical Society, 38(3), 435-448. https://doi.org/10.1111/j.1365-246X.1974.tb05423.x

Labanieh, S., Chauvel, C., Germa, A., Quidelleur, X., \& Lewin, E. (2010). Isotopic hyperbolas constrain sources and processes under the Lesser Antilles arc. Earth and Planetary Science Letters, 298(1), 35-46. https://doi.org/10.1016/j.eps1.2010.07.018

Lallemand, S., Heuret, A., \& Boutelier, D. (2005). On the relationships between slab dip, back-arc stress, upper plate absolute motion, and crustal nature in subduction zones. Geochemistry, Geophysics, Geosystems, 6(9). https://doi.org/10.1029/2005GC000917

Le Friant, A., Ishizuka, O., Stroncik, N., \& Expedition 340 scientists. (2013). Proceedings of Integrated Ocean Drilling Program (No. 340). Tokyo: IODP.

Lebrun, J. -F., \& Lallemand, S. (2017). GARANTI cruise, L'Atalante R/V. https://doi.org/10.17600/17001200

Legendre, L., Philippon, M., Münch, P., Leticée, J. L., Noury, M., Maincent, G., et al. (2018). Trench Bending Initiation: Upper Plate Strain Pattern and Volcanism. Insights From the Lesser Antilles Arc, St. Barthelemy Island, French West Indies. Tectonics, 37(9), 2777-2797. https://doi.org/10.1029/2017TC004921

Malfait, B. T., \& Dinkelman, M. G. (1972). Circum-Caribbean Tectonic and Igneous Activity and the Evolution of the Caribbean Plate. GSA Bulletin, 83(2), 251-272. https://doi.org/10.1130/0016-7606(1972)83[251:CTAIAA]2.0.CO;2

Manga, M., Hornbach, M. J., Friant, A. L., Ishizuka, O., Stroncik, N., Adachi, T., et al. (2012). Heat flow in the Lesser Antilles island arc and adjacent back arc Grenada

This article is protected by copyright. All rights reserved. 
basin. Geochemistry, Geophysics, Geosystems, 13(8).

https://doi.org/10.1029/2012GC004260

Marlowe, J. I. (1971). Dolomite, phosphorite, and carbonate diagenesis on a Caribbean seamount. Journal of Sedimentary Research, 41(3), 809-827. https://doi.org/10.1306/74D72360-2B21-11D7-8648000102C1865D

Mauffret, A., \& Leroy, S. (1997). Seismic stratigraphy and structure of the Caribbean igneous province. Tectonophysics, 283(1), 61-104. https://doi.org/10.1016/S00401951(97)00103-0

Mitchum, R. M., Vail, P. R., \& Thompson, S. (1977). Seismic Stratigraphy and Global Changes of Sea Level: Part 2. The Depositional Sequence as a Basic Unit for Stratigraphic Analysis: Section 2. Application of Seismic Reflection Configuration to Stratigraphic Interpretation, 165, 53-62.

Montes, C., Rodriguez-Corcho, A. F., Bayona, G., Hoyos, N., Zapata, S., \& Cardona, A. (2019). Continental margin response to multiple arc-continent collisions: The northern Andes-Caribbean margin. Earth-Science Reviews, 198, 102903. https://doi.org/10.1016/j.earscirev.2019.102903

Münch, P., Cornée, J. -J., BouDagher-Fadel, M., Bosch, D., Bruguier, O., Martin, C., et al. (2019). Did, and when, the Aves Ridge (Eastern Caribbean) emerge and subsequently sink? In AGU Fall Meeting Abstracts (Vol. 31).

Nagle, F. (1972). Rocks from seamounts and escarpments on the Aves Ridge. Presented at the VI Confernecia Geologica del Caribe, Margarita, Venezuela.

Nagle, F., Stipp, J. J., \& Fisher, D. E. (1976). K-Ar geochronology of the Limestone Caribbees and Martinique, Lesser Antilles, West Indies. Earth and Planetary Science Letters, 29(2), 401-412. https://doi.org/10.1016/0012-821X(76)90145-X

Neill, I., Gibbs, J. A., Hastie, A. R., \& Kerr, A. C. (2010). Origin of the volcanic complexes of La Désirade, Lesser Antilles: implications for tectonic reconstruction of the Late Jurassic to Cretaceous Pacific-proto Caribbean margin. Lithos, 120, 407-420. http://dx.doi.org/10.1016/j.lithos.2010.08.026

Neill, I., Kerr, A. C., Hastie, A. R., Stanek, K.-P., \& Millar, I. L. (2011). Origin of the Aves Ridge and Dutch-Venezuelan Antilles: interaction of the Cretaceous 'Great Arc' and Caribbean-Colombian Oceanic Plateau? Journal of the Geological Society, 168(2), 333-348. https://doi.org/10.1144/0016-76492010-067

Padron, C., Klingelhoefer, F., Marcaillou, B., Lebrun, J.-F., Lallemand, S., Garrocq, C. et al. (in press). Deep structure of the Grenada Basin from wide-angle seismic, bathymetric and gravity data. Journal of Geophysical Research: Solid Earth.

Pérez, O. J., Bilham, R., Bendick, R., Velandia, J. R., Hernández, N., Moncayo, C., et al. (2001). Velocity field across the Southern Caribbean Plate Boundary and estimates of Caribbean/South-American Plate Motion using GPS Geodesy 1994-2000. Geophysical Research Letters, 28(15), 2987-2990. https://doi.org/10.1029/2001GL013183

Pérez, O. J., Wesnousky, S. G., De La Rosa, R., Márquez, J., Uzcátegui, R., Quintero, C., et al. (2018). On the interaction of the North Andes plate with the Caribbean and South American plates in northwestern South America from GPS geodesy and seismic data. Geophysical Journal International, 214(3), 1986-2001. https://doi.org/10.1093/gii/ggy230

Philippon, M., Cornée, J.-J., Münch, P., van Hinsbergen, D. J. J., BouDagher-Fadel, M., Gailler, L., et al. (2020). Eocene intra-plate shortening responsible for the rise of a faunal pathway in the northeastern Caribbean realm. PLOS ONE, 15(10), e0241000. https://doi.org/10.1371/journal.pone.0241000

Pindell, J. L. (1994). Evolution of the Gulf of Mexico and the Caribbean. In Caribbean

This article is protected by copyright. All rights reserved. 
Geology: An Introduction (U.W.I. Publishers' Association). Kingston.

Pindell, J. L., \& Barrett, S. F. (1990). Geological evolution of the Caribbean region; A platetectonic perspective. In G. Dengo \& J. E. Case (Eds.), The Caribbean Region (pp. 405-432). Guatemala City, Guatemala: Geological Society of America. https://doi.org/10.1130/DNAG-GNA-H.405

Pindell, J. L., \& Kennan, L. (2007). Cenozoic Kinematics and Dynamics of Oblique Collision Between two Convergent Plate Margins: The Caribbean-South America Collision in Eastern Venezuela, Trinidad and Barbados. GCSSEPM.

Pindell, J. L., \& Kennan, L. (2009). Tectonic evolution of the Gulf of Mexico, Caribbean and northern South America in the mantle reference frame: an update. Geological Society, London, Special Publications, 328(1), 1-55. https://doi.org/10.1144/SP328.1

Pindell, J. L., Erikson, J. P., \& Algar, S. T. (1991). The Relationhip between Plate Motions and Sedimentary Basin Development in Northern South America: From a Mesozoic Passive Margin to a Cenozoic Eastwardly-Progressive Transpressional Orogen. In K. A. Gillezeau (Ed.), Transactions of the Second Geological Conference of the Geological Society of Trinidad and Tobago. Geological Society of Trinidad \& Tobago.

Pinet, B., Lajat, D., Le Quellec, P., \& Bouysse, Ph. (1985). Structure of Aves Ridge and Grenada Basin from multichannel seismic data (pp. 53-64). Presented at the Géodynamique des Caraïbes, Paris: Editions Technip.

Reinoza, C., Jouanne, F., Audemard, F. A., Schmitz, M., \& Beck, C. (2015). Geodetic exploration of strain along the El Pilar Fault in northeastern Venezuela. Journal of Geophysical Research: Solid Earth, 120(3), 1993-2013. https://doi.org/10.1002/2014JB011483

Ribeiro, J. M., Stern, R. J., Martinez, F., Ishizuka, O., Merle, S. G., Kelley, K., et al. (2013). Geodynamic evolution of a forearc rift in the southernmost Mariana Arc. Island Arc, 22(4), 453-476. https://doi.org/10.1111/iar.12039

Ribeiro, J. M., Stern, R. J., Kelley, K. A., Shaw, A. M., Martinez, F., \& Ohara, Y. (2015). Composition of the slab-derived fluids released beneath the Mariana forearc: Evidence for shallow dehydration of the subducting plate. Earth and Planetary Science Letters, 418, 136-148. https://doi.org/10.1016/j.epsl.2015.02.018

Sangree, J. B., \& Widmier, J. M. (1979). Interpretation of depositional facies from seismic data. Geophysics, 44(2), 131-160. https://doi.org/10.1190/1.1440957

Santamaría, F., \& Schubert, C. (1974). Geochemistry and Geochronology of the Southern Caribbean-Northern Venezuela Plate Boundary. GSA Bulletin, 85(7), 1085-1098. https://doi.org/10.1130/0016-7606(1974)85<1085:GAGOTS >2.0.CO;2

Sawyer, D., \& Mann, P. (2004). Cruise EW0404 on RV Maurice Ewing. https://doi.org/10.7284/901238

Schumann, K., Stipp, M., Behrmann, J. H., Klaeschen, D., \& Schulte-Kortnack, D. (2014). P and $\mathrm{S}$ wave velocity measurements of water-rich sediments from the Nankai Trough, Japan. Journal of Geophysical Research: Solid Earth, 119(2), 787-805. https://doi.org/10.1002/2013JB010290

Sibuet, J.-C., Deffontaines, B., Hsu, S.-K., Thareau, N., Formal, J.-P. L., \& Liu, C.-S. (1998). Okinawa trough backarc basin: Early tectonic and magmatic evolution. Journal of Geophysical Research: Solid Earth, 103(B12), 30245-30267. https://doi.org/10.1029/98JB01823

Speed, R. C., \& Walker, J. A. (1991). Oceanic crust of the Grenada Basin in the Southern Lesser Antilles Arc Platform. Journal of Geophysical Research: Solid Earth, 96(B3), 3835-3851. https://doi.org/10.1029/90JB02558

Speed, R. C., \& Westbrook, G. K. (1984). Lesser Antilles arc and adjacent terranes. In Atlas

This article is protected by copyright. All rights reserved. 
10, Ocean Margin Drilling Program (Marine Science International). Woods Hole, MA.

Speed, R. C., Smith-Horowitz, P. L., Perch-Nielsen, K. v. S., Saunders, J. B., \& Sanfilippo, A. B. (1993). Southern Lesser Antilles Arc Platform: Pre-Late Miocene Stratigraphy, Structure, and Tectonic Evolution. In Geological Society of America Special Papers (Vol. 277, pp. 1-98). Geological Society of America. https://doi.org/10.1130/SPE277p1

Stanek, K. P., Maresch, W. V., \& Pindell, J. L. (2009). The geotectonic story of the northwestern branch of the Caribbean Arc: implications from structural and geochronological data of Cuba. Geological Society, London, Special Publications, 328(1), 361-398. https://doi.org/10.1144/SP328.15

Taylor, B. (2013). Backarc Basins: Tectonics and Magmatism. Springer Science \& Business Media.

Tomblin, J. F. (1975). The Lesser Antilles and Aves Ridge. In A. E. M. Nairn \& F. G. Stehli (Eds.), The Gulf of Mexico and the Caribbean (pp. 467-500). Boston, MA: Springer US. https://doi.org/10.1007/978-1-4684-8535-6_11

Vail, P. R., Mitchum, R. M., \& Thompson, S. (1977). Seismic Stratigraphy and Global Changes of Sea Level: Part 4. Global Cycles of Relative Changes of Sea Level.: Section 2. Application of Seismic Reflection Configuration to Stratigraphic Interpretation, 165, 83-97.

van Benthem, S., Govers, R., Spakman, W., \& Wortel, R. (2013). Tectonic evolution and mantle structure of the Caribbean. Journal of Geophysical Research: Solid Earth, 118, 3019-3036. https://doi.org/10.1002/jgrb.50235

Wallace, L. M., Ellis, S., \& Mann, P. (2009). Collisional model for rapid fore-arc block rotations, arc curvature, and episodic back-arc rifting in subduction settings. Geochemistry, Geophysics, Geosystems, 10(5). https://doi.org/10.1029/2008GC002220

Weber, J. C., Dixon, T. H., DeMets, C., Ambeh, W. B., Jansma, P., Mattioli, G., et al. (2001). GPS estimate of relative motion between the Caribbean and South American plates, and geologic implications for Trinidad and Venezuela. Geology, 29(1), 75-78. https://doi.org/10.1130/0091-7613(2001)029<0075:GEORMB>2.0.CO;2

White, W., Copeland, P., Gravatt, D. R., \& Devine, J. D. (2017). Geochemistry and geochronology of Grenada and Union islands, Lesser Antilles: The case for mixing between two magma series generated from distinct sources. Geosphere, 13(5), 13591391. https://doi.org/10.1130/GES01414.1

Wright, J. E., \& Wyld, S. J. (2011). Late Cretaceous subduction initiation on the eastern margin of the Caribbean-Colombian Oceanic Plateau: One Great Arc of the Caribbean? Geosphere, 7(2), 468-493. https://doi.org/10.1130/GES00577.1

Wright, V. P., \& Burchette, T. P. (1996). Shallow-water carbonate environments. In Sedimentary Environments: Processes, Facies, and Stratigraphy. In H. G. Reading (Ed.), Sedimentary Environments: Processes, Facies and Stratigraphy (pp. 325-394). Oxford: Blackwell Science.

Ysaccis, R. (1997). Tertiary evolution of the northeastern Venezuela offshore (Thesis). Rice University, Houston, TX.

This article is protected by copyright. All rights reserved. 


\section{Appendix}

Table A1: Description, depositional environments and ages of carbonate rock samples dredged during the GARANTI cruise

Table A2: Description of seismic facies identified from GARANTI lines

This article is protected by copyright. All rights reserved. 


\section{Figure captions}

Figure 1: Regional map of the eastern Caribbean showing the main tectonic boundaries and past and present volcanic arcs. NAP, North American Plate; SAP, South American Plate; BAP, Barbados Accretionary Prism; EPF, El Pilar Fault; DF, transpressional Deformation Front in the southern Grenada Basin (Aitken et al., 2011; Pindell \& Kennan, 2007; Pinet et al., 1985; Ysaccis, 1997). Bathymetric grid: GEBCO 2014 (WGS84 Datum, UTM20N projection). The red frame delineates the study area and the location of the selected GARANTI seismic lines.

Figure 2: Bathymetric map (same data as in Figure 1) of the study area showing the locations of seismic lines (lines), wells (colored circles) and dredge sites (dots and stars).Lines with bold labels are shown in this paper. Contour interval $=250 \mathrm{~m}$.

Figure 3: Correlation of GARANTI seismic data with offshore well data (Bader et al., 1970b; Edgar et al., 1973; Ysaccis, 1997) and onshore geological observations (Speed et al., 1993). Well-seismic ties are illustrated in more detail in supporting information (Figures S1 to S4). They were made using time-depth charts from well log data. Seismic units (U0 to U3) and their discontinuities (D0 to D2b) are described in section 5.2. Thin dotted lines denote minor discontinuities. Undulating lines and "e" subscripts denote erosional unconformities.

Figure 4: Multichannel seismic data along lines a) GA21, b) GA34, c) GA02, d) GA29, and e) BOL30. Colored dotted lines denote seismic unit boundaries (detailed line-drawing in Figure 5). $\mathrm{VE}=7$. f) Close-up view of line GA02 with a superimposition of the velocity model derived from WAS data (Padron et al., in press).

Figure 5: Line-drawings of lines a) GA21, b) GA34, c) GA02, d) GA29, and e) BOL30 showing variations in basin architecture from north to south. Thick undulating lines denote erosional unconformities. Red stars indicate dredge locations. BOL30 has been reinterpreted from Aitken et al. (2011). VE=7

Figure 6: a) Depth map (below sea level) of the acoustic basement (U0) (contour interval = $0.5 \mathrm{~km}$ ); b-f) isopach maps (contour interval $=0.25 \mathrm{~km}$ ) of U1a (Early Eocene, $\sim 56-48 \mathrm{Ma}$ ), U1b (Middle Eocene, 48-38 Ma), U2a (Late Eocene-Oligocene, 38-23 Ma), U2b (Early to Middle Miocene, 23-12 Ma), and U3 (Late Miocene to Recent, 12-0 Ma). Dashed lines delineate the areas over which the calculations were made.

Figure 7: Close-up views from lines a) GA35, b) GA32, c,f) GA02, d) GA25AB and e) GA34. Colored lines denote seismic unit boundaries. $\mathrm{VE}=3.5$

Figure 8: Uninterpreted and interpreted sections of lines GA31 (left) and GA04 (right) imaging buried volcanic edifices. $\mathrm{VE}=3.5$

Figure 9: a) Amount of subsidence and b) subsidence rates at different sites of the Aves Ridge determined from dredge samples and MCS lines.

Figure 10: Tectono-structural map of the Grenada Basin. 1) Oceanic crust (smooth basement, 6-7 km thick crust); 2) transitional domain (rough basement, 7-20 km thick crust); 3) Aves Ridge crust (20-25 km thick); 4) Lesser Antilles Arc. Constraints on crustal thickness are from Padron et al. (in press), Allen et al. (2019), and Christeson et al. (2008). F1: Paleoceneearly Eocene normal faults; F2: inherited Cretaceous-Paleocene normal faults reactivated during rifting; F3: Late Oligocene-early Miocene inversion. The faults labelled 'ABC' (south of Petrel Ridge) are those interpreted in Figure 7d,e.

Figure 11: Summary of the main tectonic, magmatic, and sedimentary events in the Grenada Basin area from Late Cretaceous to present. GAC: Great Arc of the Caribbean. Timing of

This article is protected by copyright. All rights reserved. 
GAC-Bahamas collision as determined by Stanek et al. (2009). The vectors and velocities are the motion of the South American plate (SAM) relative to the central Caribbean plate (CAR), which includes the Colombian and Venezuelan basins and the Aves Ridge. These are from Matthews et al. (2016), except (1) from Pérez et al. (2018). Gray arrows represent values that appear to be outliers.

Figure 12: Cartoon showing the regional tectonic evolution from the Paleocene to the end of the Oligocene. Same fault colors as in Figure 10. Tectonic blocks modified from Pindell \& Kennan (2009).

This article is protected by copyright. All rights reserved. 


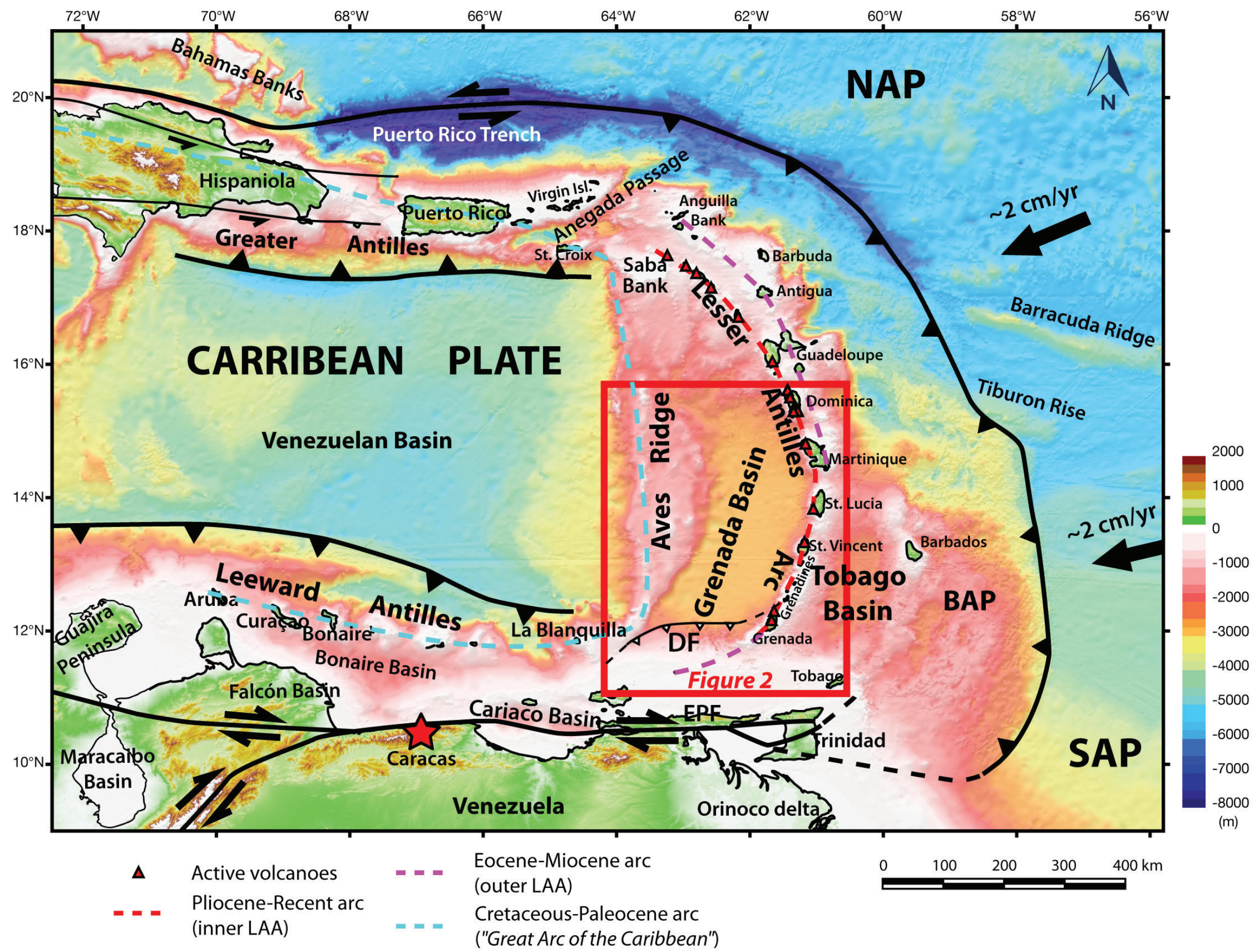




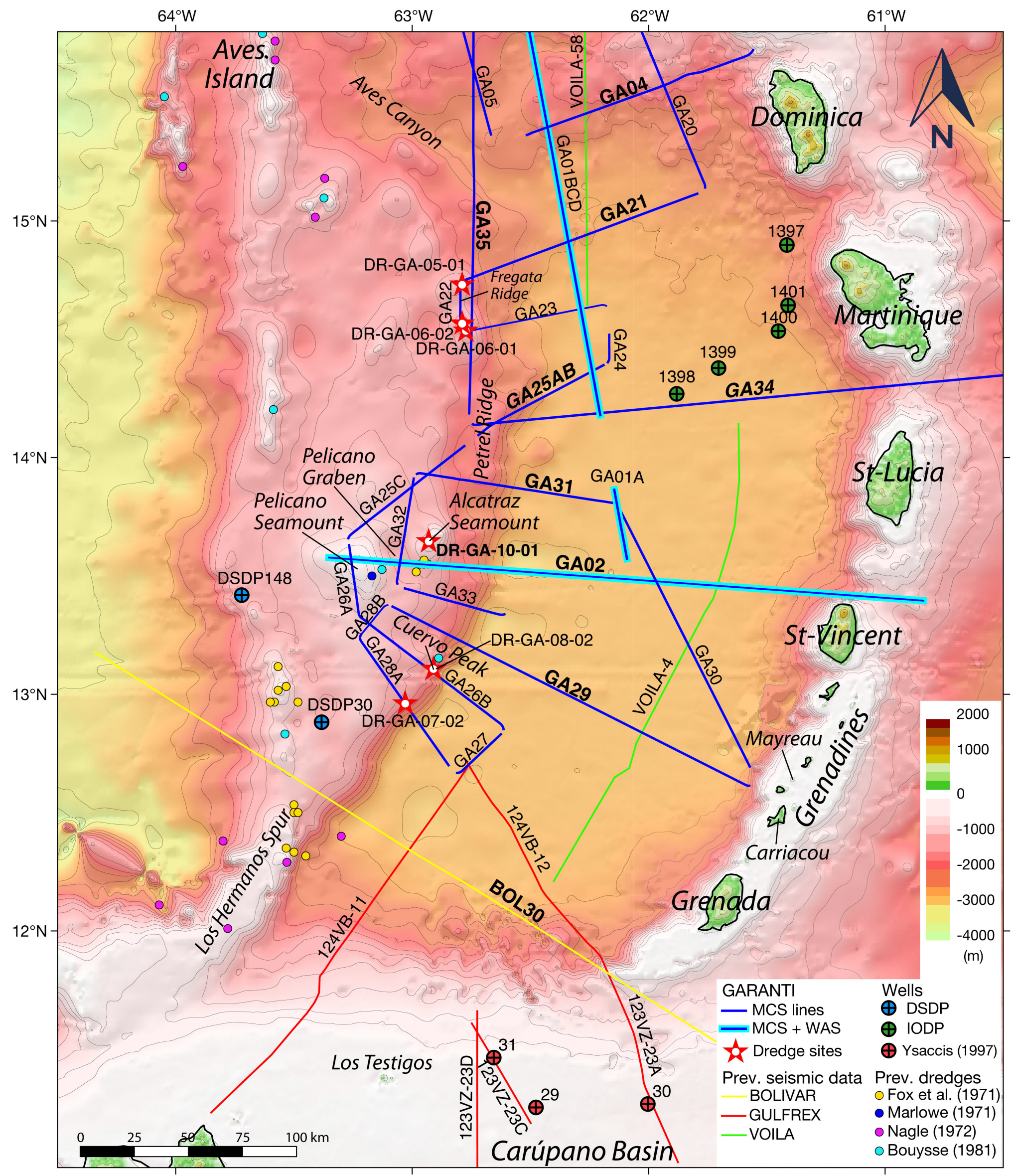

This article is protected by copyright. All rights reserved. 


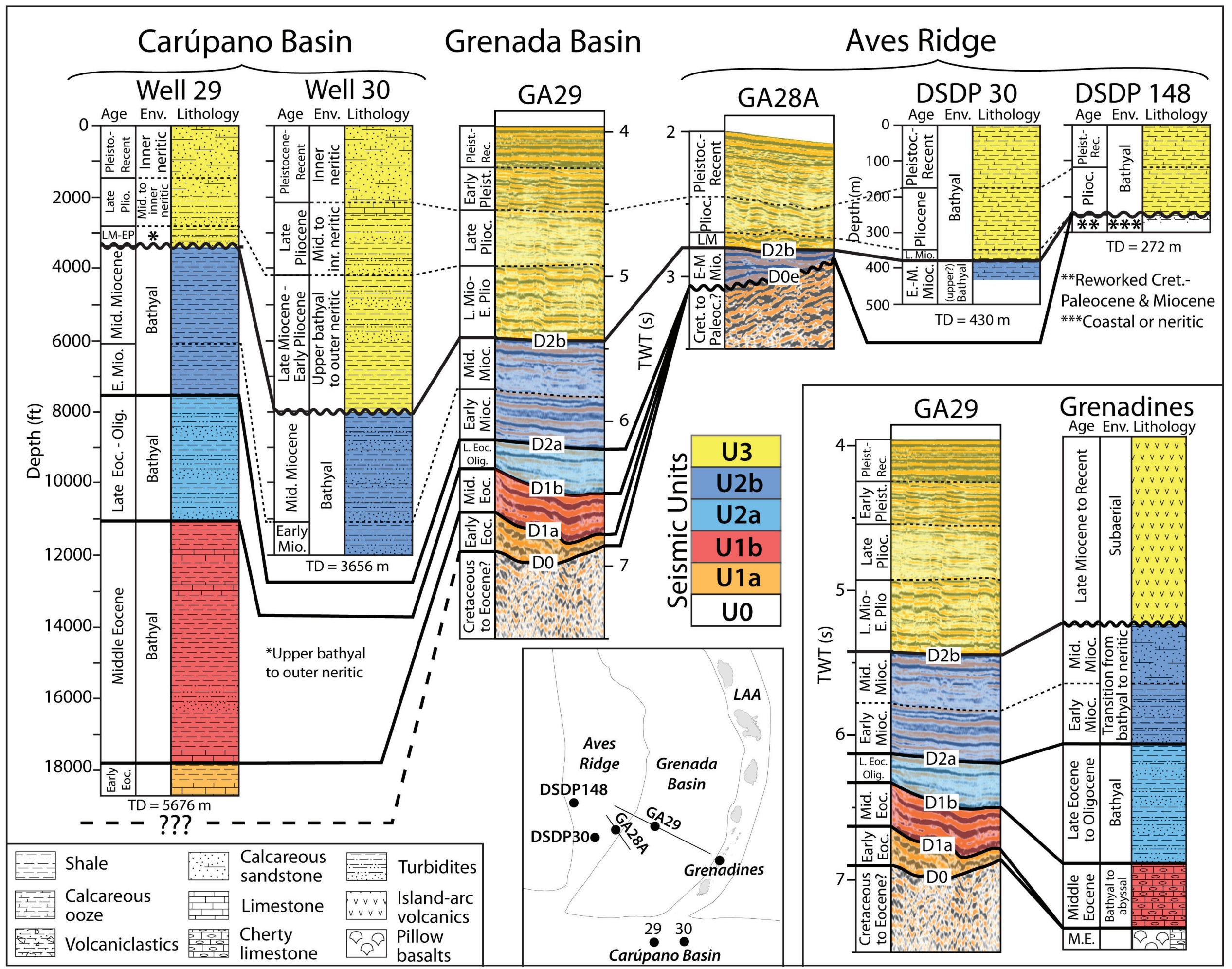




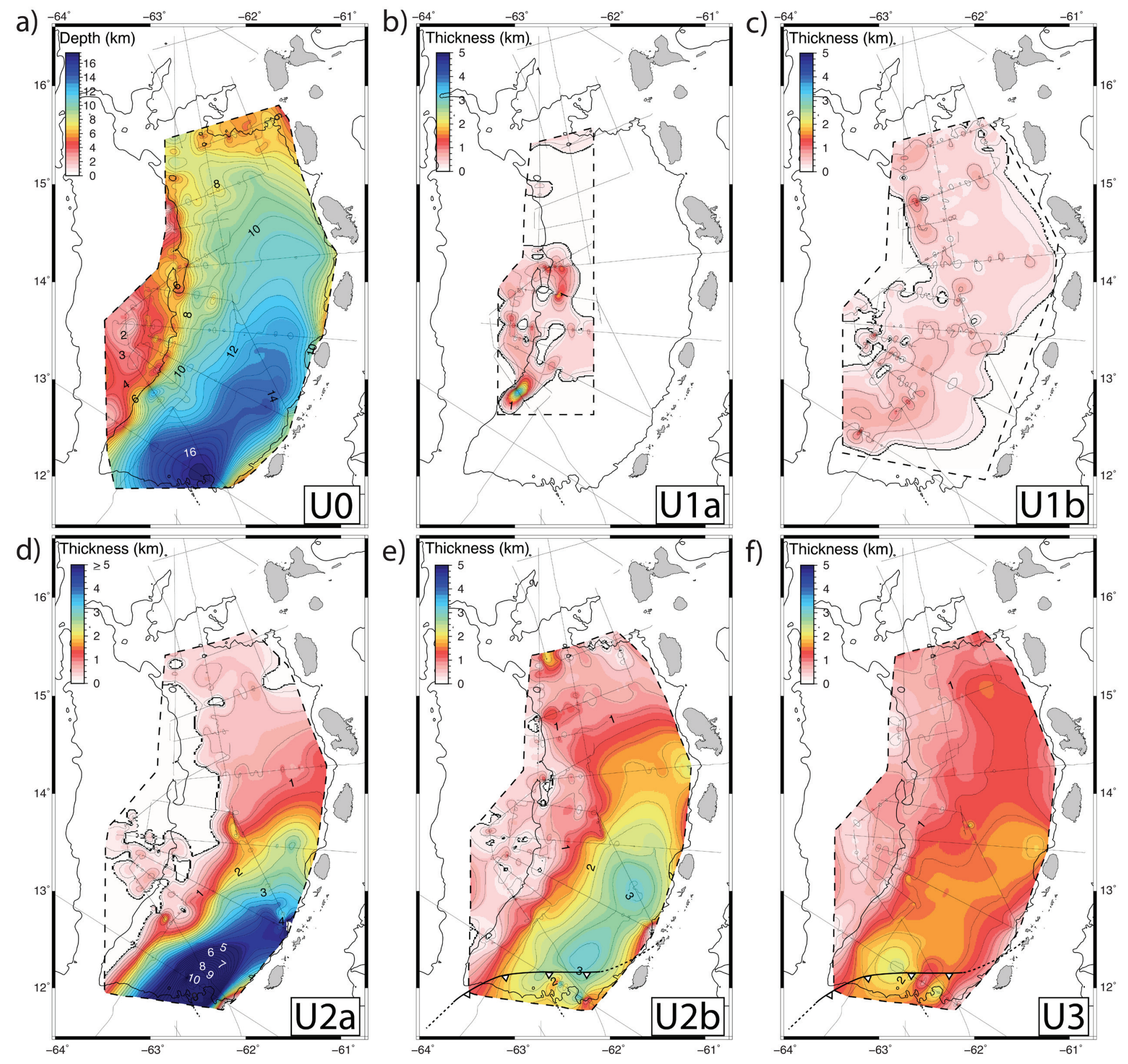




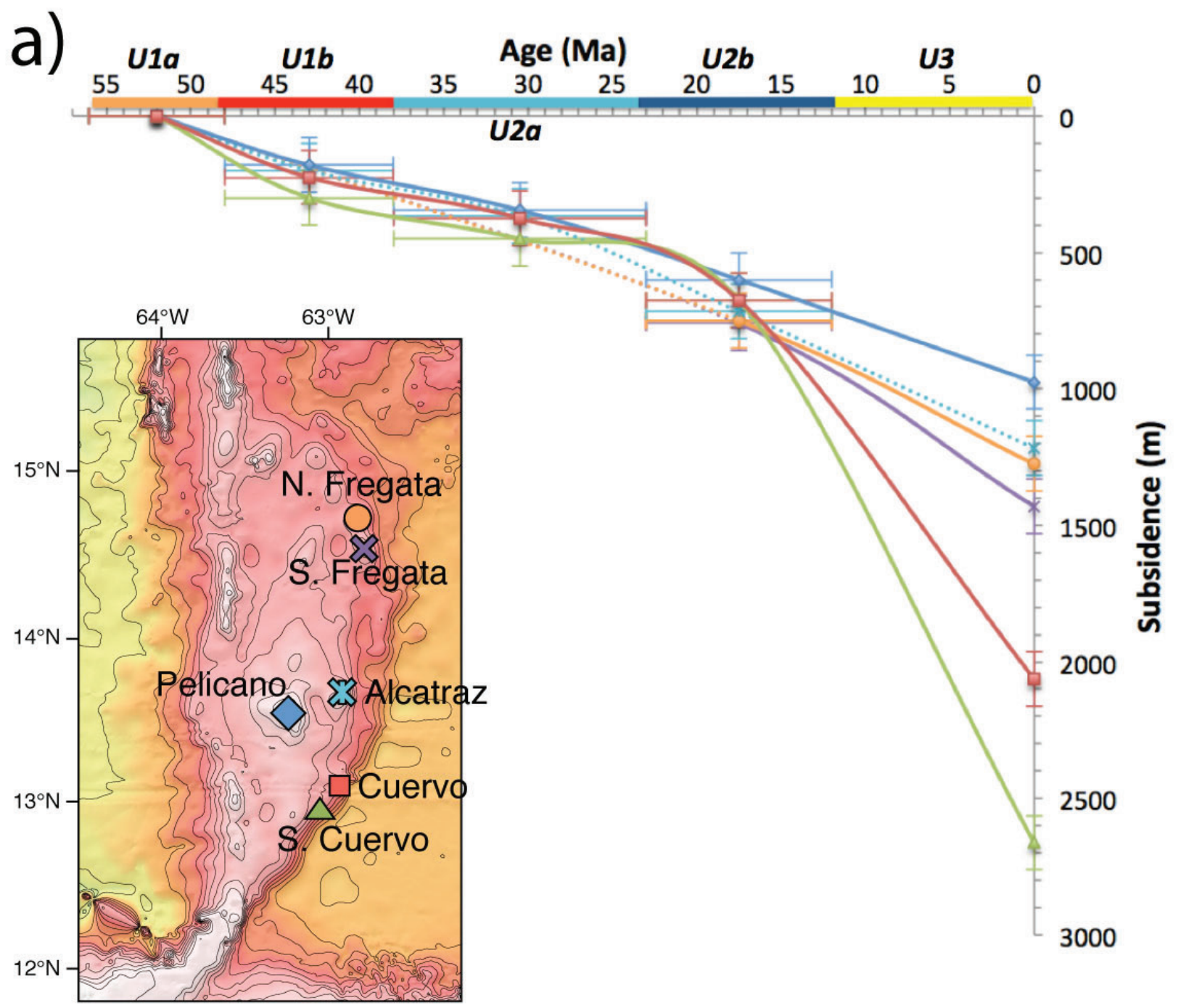

b)

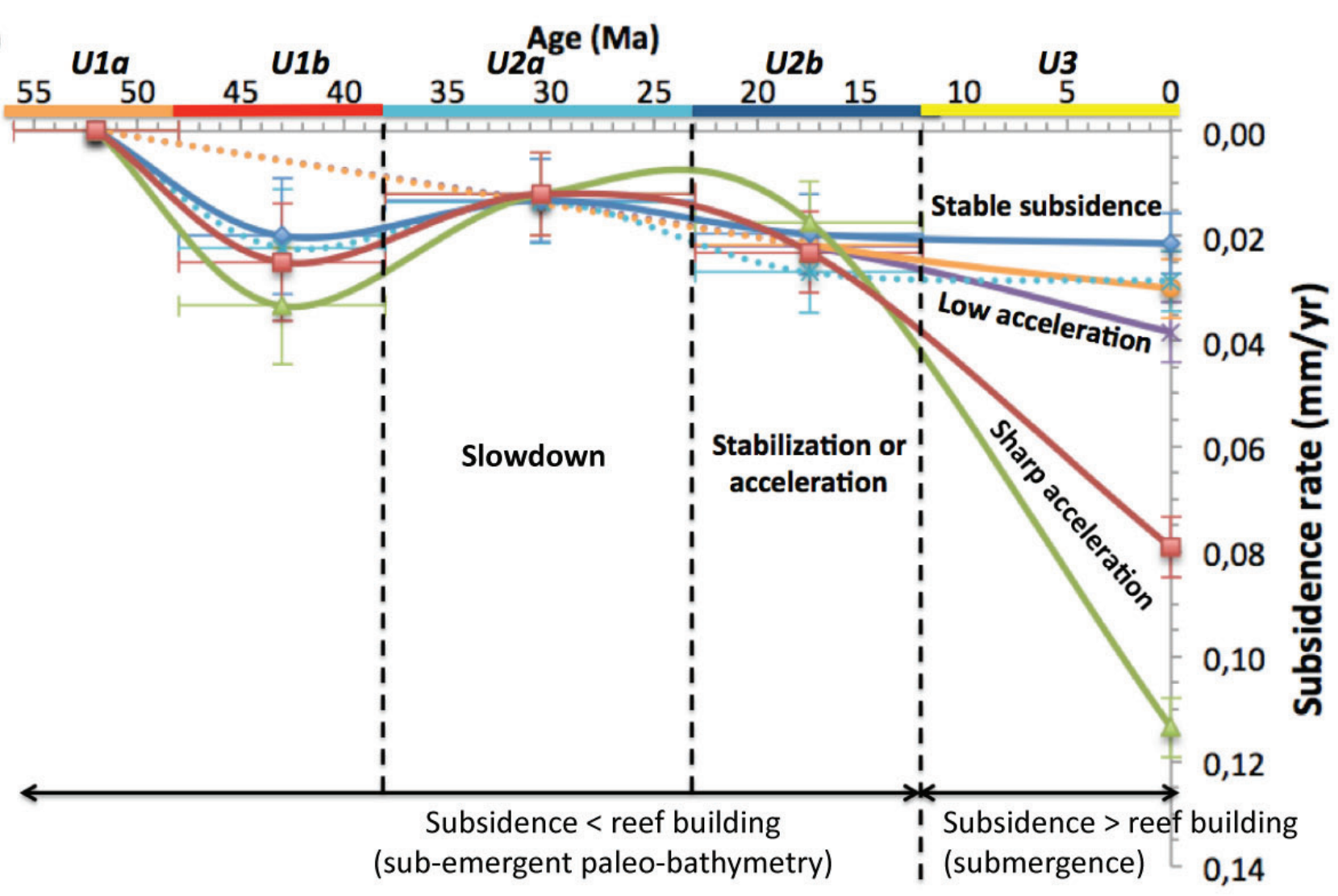




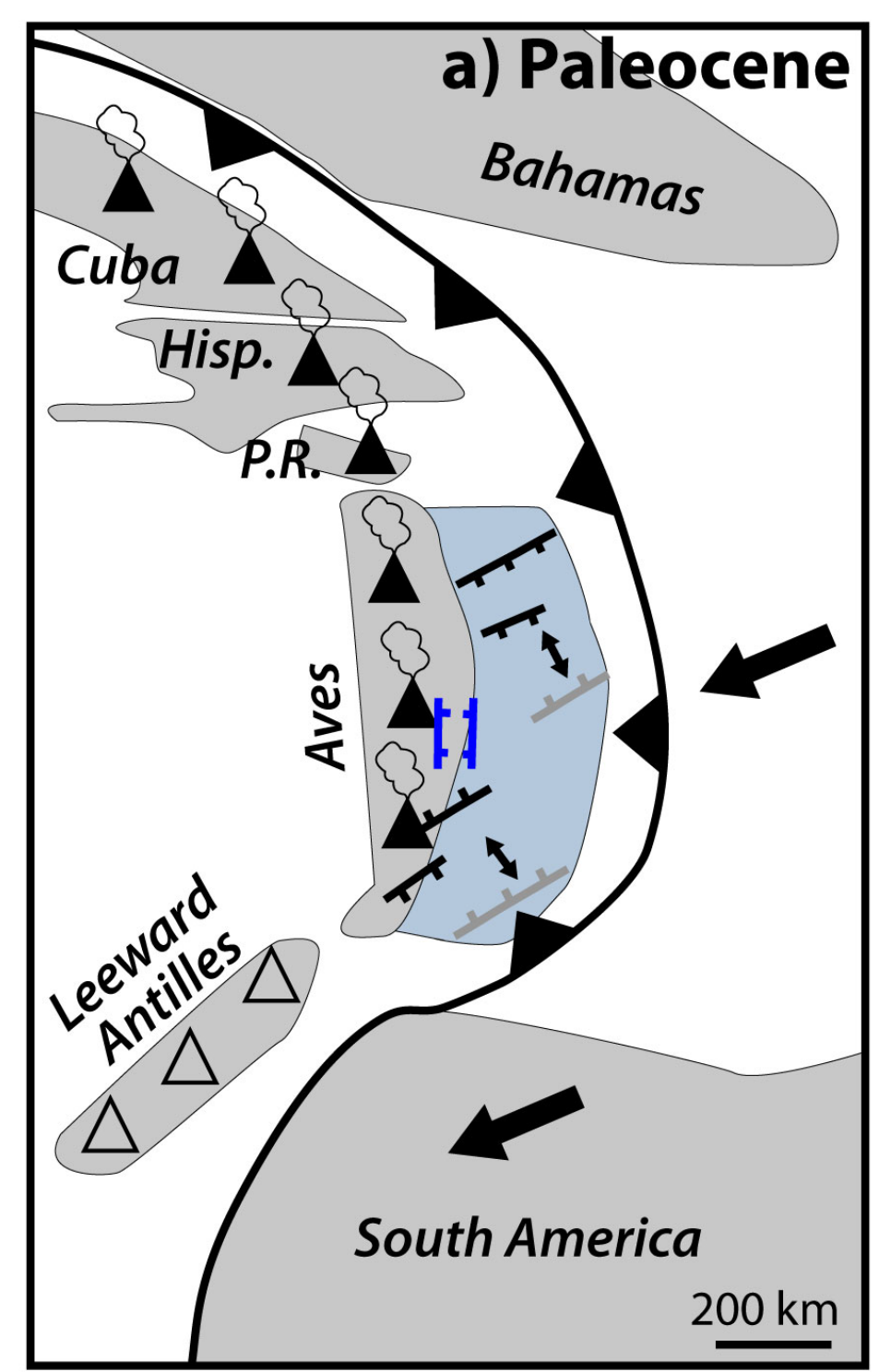

Thinned arc/forearc crust

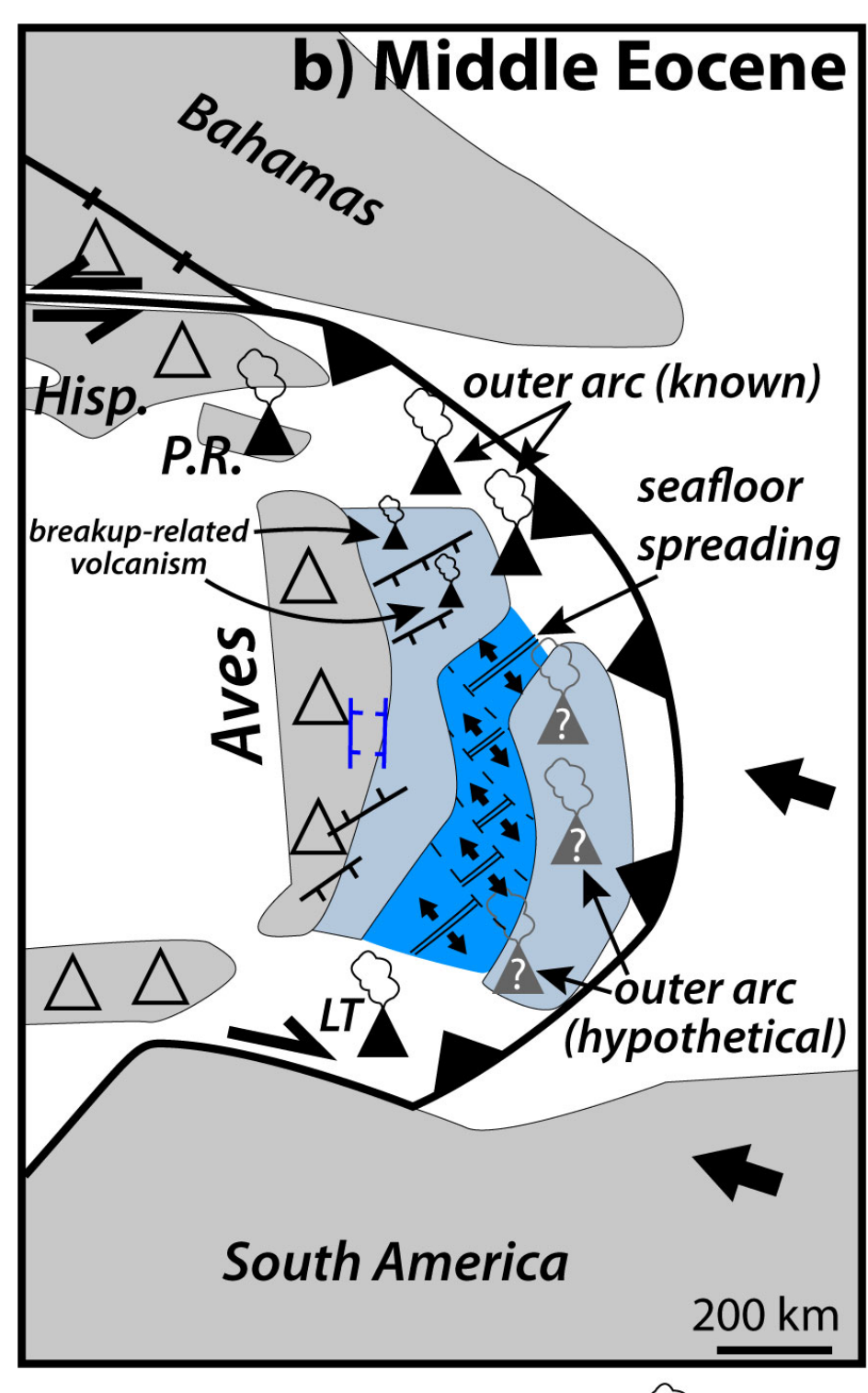

Oceanic crust

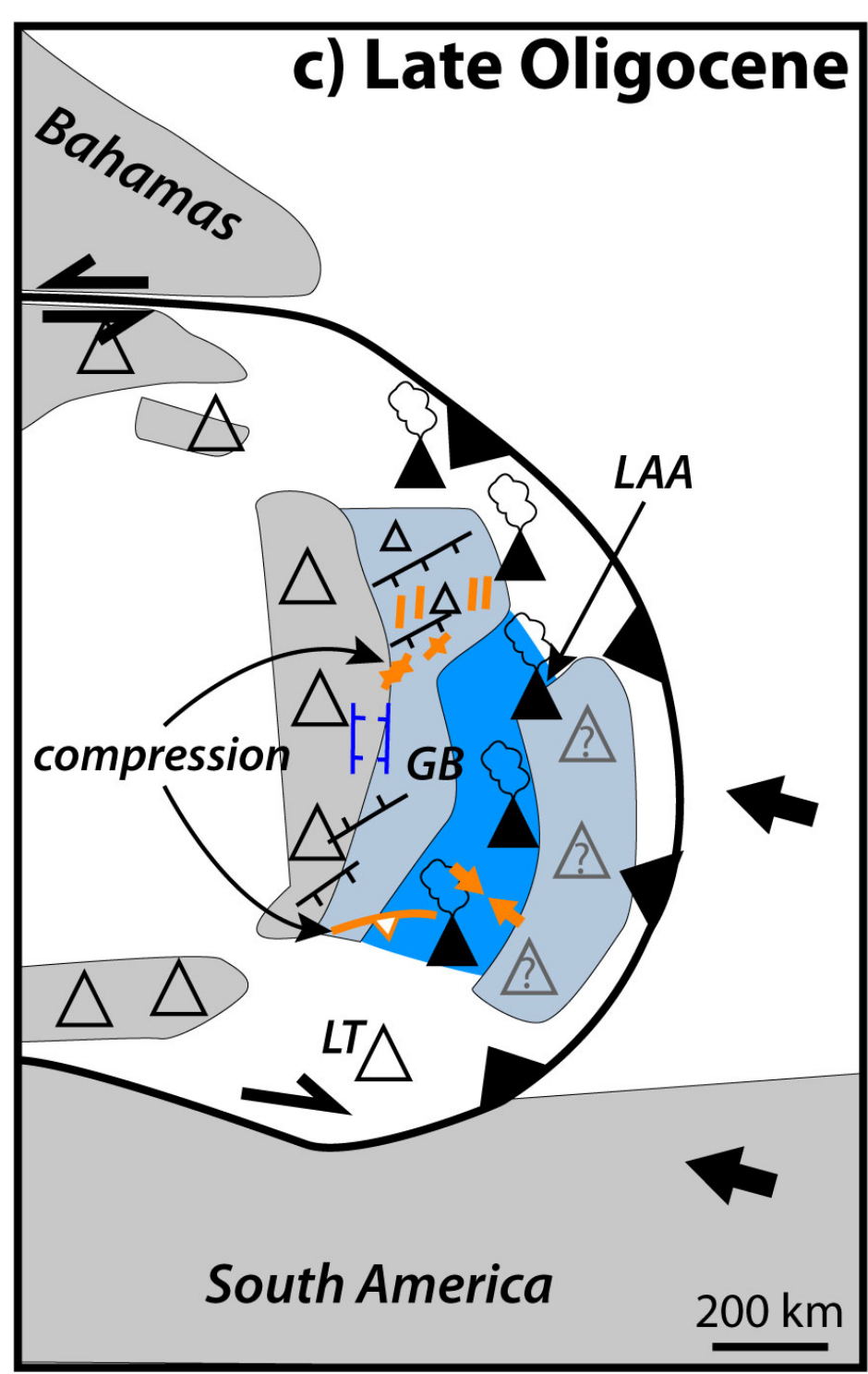

$\triangle$ Extinct volcanoes 
Table A1: Description, depositional environments and ages of carbonate rock samples dredged during the GARANTI cruise

\begin{tabular}{|c|c|c|c|c|c|c|c|}
\hline Dredge & $\begin{array}{l}\text { Depth } \\
\text { (m) }\end{array}$ & Samples & Description $^{1}$ & $\begin{array}{l}\text { Foraminiferal taxa and stratigraphic } \\
\text { ranges }^{2}\end{array}$ & Paleo-env. ${ }^{2,3}$ & $\begin{array}{l}\text { PF zones and } \\
\text { ages }^{2}\end{array}$ & Unit \\
\hline \multirow[t]{2}{*}{ DR-GA-05-01 } & $730-1170$ & $\begin{array}{l}\text { DR-GA-05- } \\
01-03\end{array}$ & Micritic crust & $\begin{array}{l}\text { Brizalina sp., Bulimina sp., Globigerina sp., Trilobatus } \\
\text { sacculifer (N5b-N23) }\end{array}$ & Outer ramp (100-200 m) & $\begin{array}{l}\text { Miocene- } \\
\text { Holocene }\end{array}$ & $\begin{array}{l}\mathrm{U} 2 \mathrm{~b}- \\
\mathrm{U} 3\end{array}$ \\
\hline & & $\begin{array}{l}\text { DR-GA-05- } \\
01-04 \mathrm{~A}\end{array}$ & Coral boundstone & $\begin{array}{l}\text { Carpenteria proteiformis, Biarritzina sp., Lepidocyclina } \\
\text { sp., L. (Lepidocyclina) canellei (N4-N5), Eulepidina sp. }\end{array}$ & Coral reef & $\begin{array}{l}\text { N4-N5, Aquitanian, 23.03- } \\
20.4 \mathrm{Ma}\end{array}$ & $\mathrm{U} 2 \mathrm{~b}$ \\
\hline \multirow[t]{3}{*}{ DR-GA-06-01 } & $995-1075$ & $\begin{array}{l}\text { DR-GA-06- } \\
01-03\end{array}$ & Coral boundstone & Miliolids and amphisteginids & Coral reef & Probably Miocene & $\begin{array}{l}\text { U2b- } \\
\text { U3? }\end{array}$ \\
\hline & & $\begin{array}{l}\text { DR-GA-06- } \\
01-05\end{array}$ & $\begin{array}{l}\text { Planktonic foraminiferal } \\
\text { and pteropod-rich }\end{array}$ & $\begin{array}{l}\text { Pulleniatina primalis, Orbulina universa, } \\
\text { Sphaeroidinellopsis subdehiscens (N12b- N19), }\end{array}$ & $\begin{array}{l}\text { Outer ramp }(100-200 \mathrm{~m}) \\
\text { or basin }\end{array}$ & N20a, Zanclean, 3.8-3.6 Ma & U3 \\
\hline & & & wackestone & $\begin{array}{l}\text { Globorotalia inflata }(\mathrm{N} 17-\mathrm{N} 23), \text { G. miocenica }(\mathrm{N} 17- \\
\text { N20a), G. menardii, G. scitula, Orbulina suturalis, } \\
\text { Globigerinoides spp., Trilobatus quadrilobatus, T. trilobus, } \\
\text { Sphaeroidinella dehiscens }(\mathrm{N} 19-\mathrm{N} 23), \text { Pulleniatina } \\
\text { obliquiloculata (N20- N23), Dentoglobigerina altispira, } \\
\text { Globoquadrina dehiscens (P22-N20a) }\end{array}$ & & & \\
\hline \multirow[t]{3}{*}{ DR-GA-06-02 } & $670-790$ & $\begin{array}{l}\text { DR-GA-06- } \\
02-02\end{array}$ & $\begin{array}{l}\text { Red algal boundstone and } \\
\text { packstone with benthic }\end{array}$ & $\begin{array}{l}\text { Operculinoides sp., Miolepidocyclina braziliana }(\mathrm{P} 21- \\
\mathrm{P} 22), \text { Miolepidocyclina } \mathrm{sp} .1, \text { Miogypsina triangulata }\end{array}$ & Inner ramp (0-20 m) & $\begin{array}{l}\text { N4-N5a, Aquitanian, } 23.03- \\
20.4 \text { Ma, with reworked }\end{array}$ & $\mathrm{U} 2 \mathrm{~b}$ \\
\hline & & & $\begin{array}{l}\text { foraminifera, green algae, } \\
\text { gastropods, some } \\
\text { planktonic foraminifera }\end{array}$ & $\begin{array}{l}\text { (P21b-N5a), M. intermedia (P21b-N8), Amphistegina } \\
\text { tuberculata (Miocene, N4-N18), Biarritzina sp., } \\
\text { Carpenteria sp., Globigerina spp., Globigerinoides spp. }\end{array}$ & & Oligocene foraminifera & \\
\hline & & $\begin{array}{l}\text { DR-GA-06- } \\
02-05\end{array}$ & $\begin{array}{l}\text { Red algal and } \\
\text { foraminiferal-rich } \\
\text { packstone }\end{array}$ & $\begin{array}{l}\text { Amphistegina sp., A. guraboensis (Miocene), A. } \\
\text { tuberculata (Miocene) }\end{array}$ & Inner ramp & Miocene & $\begin{array}{l}\text { U2b- } \\
\text { U3 }\end{array}$ \\
\hline DR-GA-07-02 & $2050-2385$ & $\begin{array}{l}\text { DR-GA-07- } \\
02-01\end{array}$ & $\begin{array}{l}\text { Packstone of red algae and } \\
\text { foraminifera }\end{array}$ & $\begin{array}{l}\text { Lepidocyclina (Lepidocyclina) yurnagunensis (Oligocene- } \\
\text { early Miocene), Amphistegina sp., Amphistegina } \\
\text { tuberculata, Miogypsina intermedia (P21b-N8), } \\
\text { Paragloborotalia kugleri (N4), Globoquadrina binaiensis } \\
\text { (P22-N5), Neogloboquadrina sp., N. continuosa (N4b- } \\
\text { N16) }\end{array}$ & $\begin{array}{l}\text { Inner to mid ramp } \\
\text { carbonates }\end{array}$ & N4b, Aquitanian, 22-21 Ma & $\mathrm{U} 2 \mathrm{~b}$ \\
\hline
\end{tabular}




\begin{tabular}{|c|c|c|c|c|c|c|c|}
\hline & & $\begin{array}{l}\text { DR-GA-07- } \\
02-01-\text {-red }\end{array}$ & $\begin{array}{l}\text { Wackestone of planktonic } \\
\text { foraminifera }\end{array}$ & $\begin{array}{l}\text { Globigerinoides spp., Globoquadrina dehiscens (P22- } \\
\text { N20a), Neogloboquadrina humerosa (N17-N22), } \\
\text { Globorotalia menardii (N17-N23), G. scitula, G. inflata } \\
\text { (N17-N23), miliolids }\end{array}$ & Basin & $\begin{array}{l}\text { N17-N20a, } \\
\text { Tortonian- } \\
\text { Zanclean, 8.6-3.6 } \\
\text { Ma }\end{array}$ & $\begin{array}{l}\mathrm{U} 2 \mathrm{~b}- \\
\mathrm{U} 3\end{array}$ \\
\hline \multirow[t]{3}{*}{ DR-GA-08-02 } & $1200-1395$ & $\begin{array}{l}\text { DR-GA-08- } \\
02-01 \mathrm{~A}\end{array}$ & $\begin{array}{l}\text { Packstone of red algae and } \\
\text { benthic } \\
\text { foraminifera, barnacles, } \\
\text { corals, echinoids }\end{array}$ & $\begin{array}{l}\text { Discocyclina californica (Eocene), Amphistegina sp., } \\
\text { Carpenteria } \mathrm{sp} ., \text { Operculinella kugleri (P18-N23), O. } \\
\text { trinitatensis (P18-N23), small miliolids, Textularia sp., } \\
\text { Turborotalia cerroazulensis (P14- P17) }\end{array}$ & $\begin{array}{l}\text { Forereef, mid ramp (20- } \\
100 \mathrm{~m})\end{array}$ & $\begin{array}{l}\text { Reworked Eocene benthic } \\
\text { foraminifers in Bartonian- } \\
\text { Priabonian deposits, P14- } \\
\text { P17, 39.2-33.9 Ma }\end{array}$ & $\mathrm{U} 2 \mathrm{a}$ \\
\hline & & $\begin{array}{l}\text { DR-GA-08- } \\
02-01 C\end{array}$ & & $\begin{array}{l}\text { Lepidocyclina sp., L. (Lepidocyclina) canellei }(\mathrm{N} 4-\mathrm{N} 5 \mathrm{a}) \\
\text { Miolepidocyclina panamensis }(\mathrm{P} 22-\mathrm{N} 8) \text {, Carpenteria sp., } \\
\text { Amphistegina sp. }\end{array}$ & $\begin{array}{l}\text { Reef to forereef, inner } \\
\text { ramp }\end{array}$ & $\begin{array}{l}\text { N4-N5a, Aquitanian, 23.03- } \\
20.4 \mathrm{Ma}\end{array}$ & $\mathrm{U} 2 \mathrm{~b}$ \\
\hline & & $\begin{array}{l}\text { DR-GA-08- } \\
02-01 \mathrm{D}\end{array}$ & & $\begin{array}{l}\text { Amphistegina canaensis, A. floridensis, Eulepidina } \mathrm{sp} ., \text { E. } \\
\text { favosa }(\mathrm{P} 21-\mathrm{N} 8 \mathrm{a}), \text { Miogypsina tani }(\mathrm{P} 21-\mathrm{N} 5 \mathrm{a}) \\
\text { Lepidocyclina } \mathrm{sp} ., \text { L. (Lepidocyclina) canellei (N4-N5) }\end{array}$ & $\begin{array}{l}\text { Inner ramp, low- } \\
\text { energy forereef }\end{array}$ & $\begin{array}{l}\text { N4-N5a, Aquitanian, 23.03- } \\
20.4 \mathrm{Ma}\end{array}$ & $\mathrm{U} 2 \mathrm{~b}$ \\
\hline DR-GA-10-01 & $700-800$ & $\begin{array}{l}\text { DR-GA-10- } \\
01-01\end{array}$ & $\begin{array}{l}\text { Wackestone of } \\
\text { foraminifera }\end{array}$ & $\begin{array}{l}\text { Lepidocyclina sp., Lepidocyclina (Lepidocyclina) canellei } \\
\text { (N4-N5), Amphistegina sp., Rotalia spp., Globigerina sp. }\end{array}$ & $\begin{array}{l}\text { Low energy forereef, inner } \\
\text { to mid ramp }(0-100 \mathrm{~m})\end{array}$ & $\begin{array}{l}\text { N4-N5, Aquitanian, 23.03- } \\
21 \mathrm{Ma}\end{array}$ & $\mathrm{U} 2 \mathrm{~b}$ \\
\hline
\end{tabular}

${ }^{1}$ Microfacies description carried out by Jean-Jacques Cornée

${ }^{2}$ Planktonic foraminifera (PF) zonal scheme and datum by (BouDagher-Fadel, 2015, 2018b), calibrated using the timescale of (Gradstein et al., 2012).

${ }^{3}$ After Wright and Burchette (1996) and (BouDagher-Fadel, 2018a) 
Table A2: Description of seismic facies identified from GARANTI lines

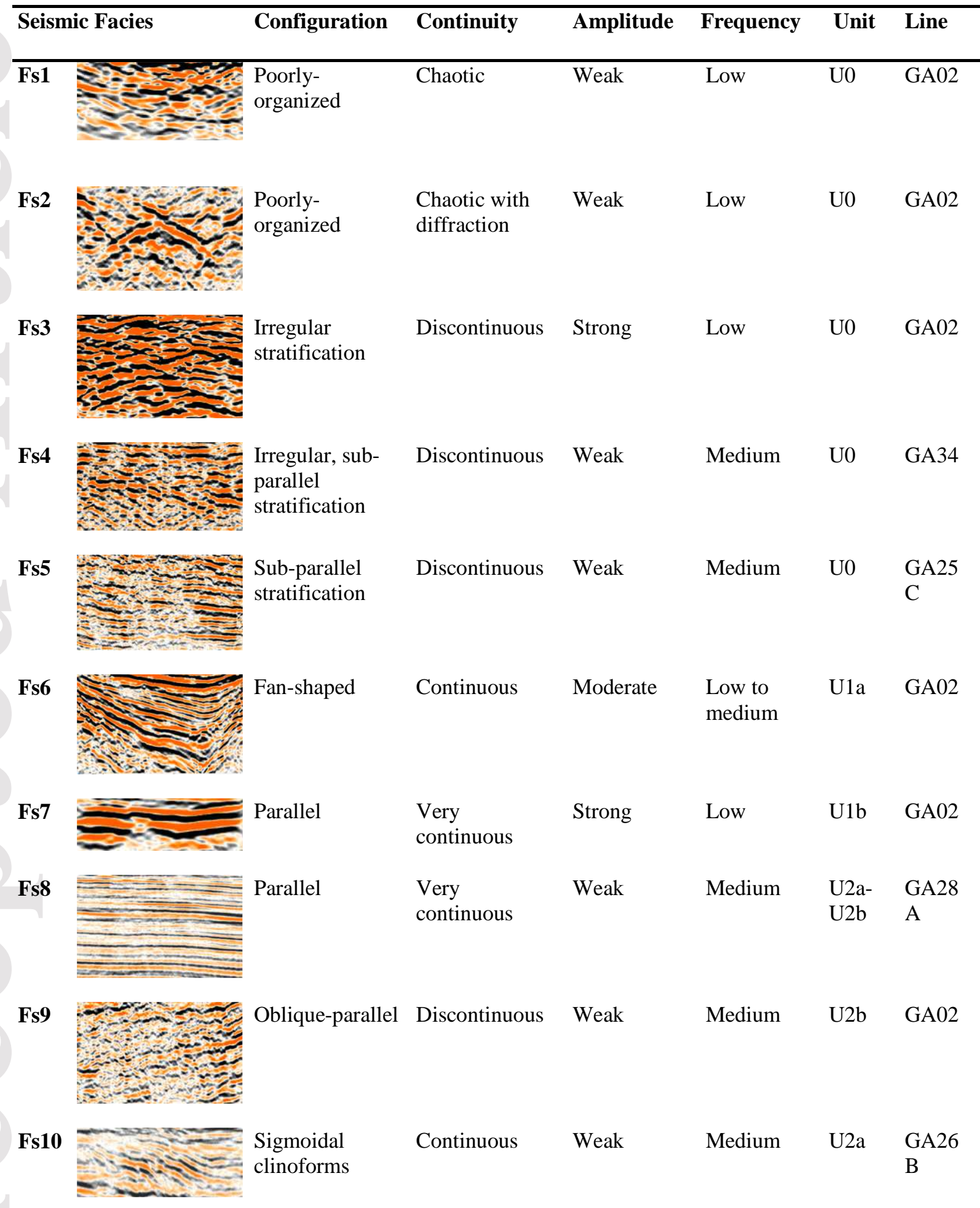

This article is protected by copyright. All rights reserved. 


\begin{tabular}{|c|c|c|c|c|c|c|c|}
\hline Fs11 & (1) & Hummocky & Continuous & Variable & High & U3 & GA02 \\
\hline Fs12 & & Parallel & $\begin{array}{l}\text { Very } \\
\text { continuous }\end{array}$ & Strong & Medium & U3 & GA02 \\
\hline Fs13 & & Oblique-parallel & Continuous & $\begin{array}{l}\text { Moderate to } \\
\text { strong }\end{array}$ & Medium & $\mathrm{U} 3$ & GA02 \\
\hline Fs14 & ends & Hummocky & Discontinuous & Variable & High & $\mathrm{U} 3$ & $\begin{array}{l}\text { GA28 } \\
\text { A }\end{array}$ \\
\hline Fs15 & 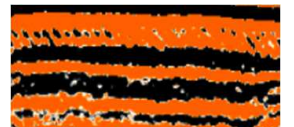 & Parallel & $\begin{array}{l}\text { Very } \\
\text { continuous }\end{array}$ & Strong & Low & $\begin{array}{l}\text { U1b- } \\
\text { U2b }\end{array}$ & GA02 \\
\hline
\end{tabular}

This article is protected by copyright. All rights reserved. 